\title{
Brazilian consensus on guidelines for diagnosis and treatment for restless legs syndrome
}

\section{Consenso Brasileiro para as diretrizes de diagnóstico e tratamento da síndrome das pernas inquietas}

Alan Christmann Fröhlich ${ }^{1}$, Alan Luiz Eckeli², Andrea Bacelar ${ }^{3}$, Dalva Poyares ${ }^{4}$, Daniela Vianna Pachito ${ }^{15}$, Fernando Gustavo Stelzer ${ }^{5}$, Fernando Morgadinho Santos Coelho ${ }^{6}$, Geraldo Nunes Vieira Rizzo ${ }^{5}$,

Gilmar Fernandes do Prado ${ }^{6}$. Heidi Haueisen Sander², Leonardo lerardi Goulart?'

Ligia Mendonça Lucchesi ${ }^{4}$, Livia Leite Góes Gitai ${ }^{8}$, Lucila Bizari Fernandes do Prado ${ }^{6}$, Luiz Ataíde-Junior ${ }^{9}$, Marcio Luciano de Souza Bezerra ${ }^{10}$, Maria Cecilia Lopes ${ }^{11}$, Marine Meliksetyan Trentin ${ }^{12}$,

Raimundo Nonato Delgado Rodrigues ${ }^{13}$, Rosa Hasan ${ }^{11}$, Rosana S. Cardoso Alves ${ }^{11}$,

Suzana Veiga Schönwald ${ }^{14}$, Walter André dos Santos Moraes ${ }^{4}$

\begin{abstract}
The Consensus on restless legs syndrome is an effort of neurologists from several Brazilian states, which tirelessly reviewed the literature of recent years in search of evidence, both in regard to diagnosis and treatment, according to the Oxford Centre for Evidence-based Medicine.
\end{abstract}

Keywords: restless leg, diagnostic criteria, treatment.

RESUMO

O Consenso em síndrome das pernas inquietas contou com a participação de neurologistas de vários estados brasileiros, os quais incansavelmente revisaram a literatura dos últimos anos em busca de evidências, tanto no que se refere ao diagnóstico como ao tratamento, de acordo com a Classificação do Centro de Oxford para Medicina Baseada em Evidências.

Palavras-chave: pernas inquietas, critérios diagnósticos, tratamento.

Protocols or guidelines presented here seek to systematize the available knowledge and offer a gold standard pattern of clinical management, scientifically safer and consistent for restless legs syndrome. They are evidencebased recommendations, developed from a review of an updated scientific literature.

\footnotetext{
${ }^{1}$ Serviço de Neurologia e Neurocirurgia, Passo Fundo RS, Brazil;

${ }^{2}$ Universidade de São Paulo, Faculdade de Medicina de Ribeirão Preto, Ribeirao Preto SP, Brazil;

${ }^{3}$ Clínica Carlos Bacelar, Rio de Janeiro RJ, Brazil;

${ }^{4}$ Universidade Federal de São Paulo, Departamento de Psicobiologia, Sao Paulo SP, Brazil;

${ }^{5}$ Hospital Moinhos de Vento, Porto Alegre RS, Brazil;

${ }^{6}$ Universidade Federal de São Paulo, Departamento de Neurologia, Sao Paulo SP, Brazil;

${ }^{7}$ Hospital Israelita Albert Einstein, Sao Paulo SP, Brazil;

${ }^{8}$ Universidade Federal de Alagoas, Faculdade de Medicina, Maceió AL, Brazil;

${ }^{9}$ Universidade Federal de Pernambuco, Recife PE, Brazil;

${ }^{10}$ Clínica Rio-Sono, Rio de Janeiro RJ, Brazil;

${ }^{11}$ Universidade de São Paulo, Faculdade de Medicina, Hospital das Clínicas, Sao Paulo SP, Brazil;

${ }^{12}$ Pontifícia Universidade Católica do Rio Grande do Sul, Hospital São Lucas, Serviço de Neurofisiologia Clínica, Porto Alegre RS, Brazil;

${ }^{13}$ Universidade de Brasília, Faculdade de Medicina, Brasília DF, Brazil;

${ }^{14}$ Hospital de Clínicas de Porto Alegre, Porto Alegre RS, Brazil;

${ }^{15}$ ProSSono - Centro de Medicina do Sono, Ribeirao Preto, Brazil.
}

Correspondence: Geraldo Nunes Vieira Rizzo; Hospital Moinhos de Vento, Departamento de Neurologia; Rua Tiradentes, 333 / $11^{\circ}$ andar; $90560-030$ Porto Alegre RS, Brasil; E-mail: geraldorizzo@gmail.com

Conflict of interest: There is no conflict of interest to declare.

Received 24 October 2014; Received in final form 15 November 2014; Accepted 04 December 2014. 


\section{BRIEF HISTORY}

The first known description in Western Medicine that resembles the framework of Restless Legs Syndrome (RLS) ${ }^{1}$ - even if not sure of the specific diagnosis ${ }^{2}$, date of 1685 , in the work of Thomas Willis: "the London Practice of Physick", in the chapter on sleep disorders (Instructions and prescripts for the curing Watching Evil, and the Watching Coma). The description includes several key features of RLS as feeling restless, occurring at rest, lying in bed, and with movements of the limbs, both lower and upper, preventing sleep, and recommend treatment with opiates (laudanum or tincture opium) $)^{3}$.

In 1945, Dr. Karl-Axel Ekbom, a swedish neurologist, did a complete characterization of this new clinical entity and coined the term "restless legs syndrome" with two distinct forms: one paresthesic and one painful ${ }^{4}$.

Due to the descriptions of these two authors, recently the International Restless Legs Syndrome Study Group (IRLSSG) recommended the use of the eponym Willis-Ekbom Disease in RLS.

In 1953, Nordlander described the relevance of iron in RLS treatment ${ }^{5}$. The relationship between RLS and periodic limb movements (PLMS) was established in Bologna in $1962^{6}$. The modern RLS treatment begun in 1982, when Sevket Akpinar suggested the use of levodopa in this condition ${ }^{7}$. Nowadays, RLS is increasingly recognized as a very frequent condition, affecting around $6 \%$ Brazilian adults ${ }^{8}$. Even so, RLS still is a very underrecognized condition?

In 1995 IRLSSG has been formed as an international group of researchers on the subject, establishing diagnostic criteria for RLS. These criteria were subsequently modified in $2003^{10}$. In 2005 , the $2^{\text {nd }}$ International Classification of Sleep Disorders included RLS among movement disorders related to sleep. In 2011, the criteria for RLS were again modified as a IRLSSG recommendation $^{11}$ (Table 1).

\section{DIAGNOSTIC CRITERIA}

RLS is a sensory-motor neurological disease whose main symptom is an overwhelming need or urge to move the legs that occurs during periods of rest and inactivity, with a circadian variation, worse at night, which affects sleep and affects the quality of individual's life. This symptom may affect one or both legs, and in some cases can affect other parts of the body like the upper limbs. Disease expression is variable and symptoms can occur daily or once a year, with mild to very grave intensity ${ }^{10,12,13}$. Additionally, symptoms may show spontaneous remission for varying periods of time, returning hereafter ${ }^{10}$.

The diagnosis of RLS is clinical, based solely on reported symptoms and/or observed in the patient. In 2011, IRLSSG has modified the diagnostic criteria for RLS, suggesting five key criteria - which should all be present - and supporting criteria $^{11}$.

The need or urge to move the legs, usually accompanied by discomfort or annoyance

The first essential criterion refers to the primary symptom of RLS: the need or urge to move the legs, which often is strong and compelling, becoming progressively greater

Table 1. Restless legs syndrome diagnostic criteria.

( 1 ) The need or urge to move the legs, usually accompanied by discomfort or annoyance

( 2 ) Symptoms are worse or exclusively present at rest or inactivity: sitting or lying

( 3 ) Relieving symptoms totally or partially with the movement

( 4 ) The perceived symptoms during rest and inactivity worsen or occur exclusively at night

( 5 ) The above symptoms are not better explained by other diseases or conditions

Support Criteria for the Diagnosis of Restless Legs Syndrome

Positive family history

Clinical course

Positive response to dopaminergic agonist

High PLM index on PSG

Remarks

Eventually the need and/or urge to move the legs may be present without the associated symptoms. Involvement of other areas of the body like the upper limbs .

For children, the description of these symptoms should be taken by their own words.

When symptoms are very pronounced, relief for the activity can not be perceived, but was previously present.

When symptoms are very intense, worse at night can not be observed but should be previously present.

Conditions that mimic RLS often have been confused with this syndrome, particularly in epidemiological surveys and RLS can also be present with them.

The criterion of clinical symptoms does not apply to pediatric cases and even some cases of RLS in pregnancy as those caused or induced by drugs, in which the frequency can be high but limited to the duration of the predisposing condition.

IRLSSG: International Restless Legs Syndrome Study Group; PLM: Lower Limb Movements Periodicals; PSG: Polysomnography. Adapted of 11. 


\begin{tabular}{ll}
\hline Inquietação, incômodo & Queimação, calor \\
Irritação & Choque \\
Fisgada, picada & Estrangulamento, contração \\
Dormência & Dor, dor no osso, dor "no fundo" \\
Cansaço & Angústia, ansiedade, desespero, aflição, tensão \\
Coceira, comichão & Sensação de pernas nervosas \\
Formigamento, “formigação" & "Ruindade" \\
Sensação de peso & "Cãibras" \\
Repuxamento & Pinicar, "pinicamento" \\
Vontade de não ficar quieto & Friagem nos ossos \\
Cócega & Regionalmente \\
Vontade de espichar & "Farnizim” \\
“Um bicho dentro da perna" & "Gastura" \\
\hline
\end{tabular}

Words and phrases without english translation.

when relief maneuvers are not performed. This need or urge to move the legs may or may not be associated with other unpleasant and uncomfortable symptoms, perceived deep in the legs between the knees and ankles, which occur without an apparent stimulus ${ }^{10,11,13}$. Thus, these unpleasant sensations are not mandatory or necessary for the diagnosis, but if they occur, are manifested in association with the need to move the legs. These sensations are perceived usually in the legs, between the knee and ankle, but may involve other areas of the body such as the arms, abdomen and genitalia. However, the involvement of other isolated areas of the body besides the legs are unusual ${ }^{10,11}$.

The unpleasant sensation is generally difficult to be set by the patient and can include pain, but does not refer to cramps (even though the patient may erroneously describe the symptoms of this form). In cases where there are only cramps, with pain associated with involuntary muscle contraction, another diagnosis besides RLS must be sought ${ }^{10,11}$. The sensation described by the patient can include many adjectives and terms here writen in Portuguese and English ${ }^{8,10,14,15}$ (Tables 2 and 3).

\section{Symptoms are worse or exclusively present at rest or inactivity: sitting or lying}

The second essential criterion states that the symptoms of necessity or urgency to move the legs occur or worsen during periods of rest or inactivity such as, for example, sitting or lying down. For rest and inactivity should be understood not only physical immobility, but also cognitive inactivity, since increased alertness (as occurs in intense intellectual activity, such as chat, games video games) can reduce the intensity of symptoms ${ }^{10}$. Most patients relate that symptom intensity increases with longer rest period or inactivity $^{10}$. There is no specific body position that produces symptoms, so they can occur in any position as long as the rest and inactivity are suficient prolonged ${ }^{10}$.

Situations typically related to symptoms include moments when the individual is at prolonged rest or have the leg movements restricted, such as: watching TV, religious cults, travel (sitting), meetings, theatre, cinema, dining, etc. If the symptoms resolve or improve with rest, one must contemplate another diagnosis.

\section{Fully or partially alleviate symptoms with the movement}

This criterion stablish that the urgency or need to move the legs and the associated symptoms improved in whole or in part with the movement and that this relief remains while the movement is continued. The more intense the movement, the greater relief of symptoms. For symptomatic improvement, the individual adopts different strategies, such as walk, stretch, move, shake, actively swing the legs or with passive movements as massage ${ }^{10}$. Besides movement,

Table 3. Restless legs syndrome symptomatology.

Restlessness, nuisance
Irritation
Sting
Numbness
Tiredness
Itching
Tingling
Heaviness
Desire to move
Tickle
Willingness to broach
A critter inside leg
Burning, heat
Shock
Strangulation, contraction
Pain, bone pain, pain "in the background"
Distress, anxiety, despair, grief, tension
Feeling nervous legs
Badness
Cramps
Chill in the bones
"Farnizim"
"Gastura"

Modified 8,10,14,15. 


\begin{tabular}{ll}
\hline Insomnia & Vascular insifficiency \\
Renal failure & Iron deficiency anemia \\
Hepatic failure & Use of alcohol \\
COPD & Use of caffeine \\
Fibromyalgia & Medicines \\
Multiple Sclerosis & Metoclopramide \\
Parkinson's disease & Antihistamines \\
Charcot-Marie type II & Lithium carbonate \\
Gastrectomy or bariatric surgery & Neuroleptic dopamine antagonists \\
Gestation & Antidepressants (except bupropion) \\
Rheumatoid arthritis & Levothyroxine \\
\hline
\end{tabular}

Modified 10,29

symptomatic improvement may also be due to hot or cold baths and even intense intellectual activities such as reading, talking, watching $\mathrm{TV}^{10}$.

In cases where the symptoms are very severe, the relief by movement may not be noticed, but it was previously present $^{10,11}$. Movements typically referred by the patients include: walking, stretching, crash grounded, massaging, hot bath, regionally, rubbing or shaking legs. It is observed that the relief persists while the movement is performed and this should be continued (not just only one motion for relief or improvement of symptoms).

The perceived symptoms during rest and inactivity worsen or occur exclusively at night

The fourth essential criterion refers to the circadian characteristic of RLS, with worsening of symptoms in the afternoon and evening. When the patient's symptoms are more severe, symptoms may occur at other times of the day. However, the patient will be able to remember that these were earlier more intense in the afternoon or at night ${ }^{10,11}$.

The above symptoms are not better explained by other diseases or conditions:

- Myalgia

- Venous Stasis

- Edema of the lower limbs

- Arthritis

- Cramps

- Positional Discomfort

- Rhythmic movements such as tics and lower limbs mannerisms

- Leg swinging

\section{CLINICAL EVOLUTION}

(A) Chronic persistent RLS: symptoms, if left untreated, may occur on average at least twice a week in the past year;

(B) Intermittent RLS: symptoms, if left untreated, occur on average less than twice a week, in the last year, with at least 5 episodes throughout life.

\section{CLINICAL RELEVANCE}

RLS symptoms cause distress or impairment in social, occupational, educational or other important areas of functioning by the impact on sleep, on the sense of energy and vitality, on daily activities, behavior, cognition or mood.

\section{SUPPORTING CRITERIA FOR RLS DIAGNOSIS}

In addition to the RLS essential diagnostic criteria supporting criteria allow greater diagnostic certainty ${ }^{11}$.

\section{Positive family history}

It can often be identified among carriers of the condition, it is estimated that first-degree relatives are at 3-5 times risk to develop RLS ${ }^{10,12}$. The earlier onset of RLS symptoms - before the 34 to 45 years old - indicates an increased family risk ${ }^{12}$.

\section{Clinical course}

Two distinct RLS phenotypes are recognized: (1) primary or familiar with a genetic predisposition and an earlier onset of symptoms; (2) secondary, associated with iron deficiency conditions (iron deficiency anemia, pregnancy, frequent blood donation, renal failure), with other clinical and neurological disorders and substances (Table 4). RLS is considered a chronic disorder, especially the idiopathic form, with progression of symptoms in the course of its evolution. The evolution of secondary RLS is related to the underlying disease, with the possibility of remission of symptoms as occurs, for example, after pregnancy or renal transplant.

\section{Positive response to dopamine agonist}

Practically all patients with RLS have an initial response to the treatment with dopaminergic agents (levodopa or dopamine agonists - see treatment section) at doses lower than those used for the treatment of Parkinson's disease. In fact, approximately $90 \%$ of patients treated with dopaminergic agents referred some symptomatic relief. Therefore, the symptomatic response to relatively low doses of these 
drugs is highly suggestive of RLS diagnosis ${ }^{10,13}$. The levodopa test, consisting on the administration of levodopa- benserazide at a dose of 100/25 mg showed a high sensitivity (80\%-88\%) and specificity (100\%) for the diagnosis of RLS ${ }^{16}$. Furthermore, administration of dopamine antagonists such as antipsychotics and antiemetics, result in increased intensity of symtoms $^{13}$.

\section{High PLM index on PSG}

The periodic movements of the lower limbs, both awake as in sleep, are considered as the motor expression of RLS. ${ }^{12}$ It is estimated that around $80 \%$ of patients with RLS exhibit periodic limb movements in sleep. This number is lower in children. PLMS are non-specific for the diagnosis of RLS because they often occur in association with other disorders such as narcolepsy, REM sleep behavior disorder, obstructive sleep apnea (OSA) and even in normal individuals (especially the elderly) ${ }^{10,13}$.

\section{EPIDEMIOLOGY}

The prevalence of RLS is between $5 \%-10 \%^{17,18,19,20}$. In a study conducted in a Brazilian city, RLS prevalence was estimated at $6.4 \%^{8}$. There was an increasing prevalence by age and a greater involvement of women, at a rate of two women to one man. Possible explanations for the higher prevalence in women include: (1) that women perceive and report symptoms differently from men, (2) the presence of hormonal differences among genders, (3) the reduction of iron stores in women.

Furthermore, pregnancy may be an important risk factor to develop RLS in those women who have a family history of RLS. The effect of pregnancy justified most of the difference in the prevalence of RLS among genders ${ }^{21}$.

It has been recurrently observed a decrease in the prevalence of RLS in individuals older than 60/70 years of age ${ }^{17,18,22}$. Men with RLS, compared to individuals without RLS, have higher mortality independent to other known risk factors such as cancer, cardiovascular disease and hypertension ${ }^{23}$.

\section{DIFFERENTIAL DIAGNOSIS 24,25,26,27,28}

- Neuroleptic-induced akathisia

- Hypotensive akathisia

- Peripheral neuropathy

- Lumbar radiculopathy and myelopathy

- Vascular and neurogenic claudication

- Chronic pain syndrome (lumbar, cervical)

- Fibromyalgia

- Arthritis of the lower limbs

- Positional Discomfort
- Nocturnal cramps

- Sleep Myoclonus

- Depression

- Voluntary movements, such as swinging the legs or tapping the feet, are observed in anxiogenic and tedious situations

- Peripheral vascular insufficiency and varicose veins

- Painful legs and moving toes

- Curse of Vesper

- Growing pains in children

Allen and Earley ${ }^{24}$ highlight six key points in the differential diagnosis of RLS in relation to other diseases:

(i) RLS is triggered by rest and not related to another activity previously performed by the individual. This feeling, though not related to a specific position, occurs when remaining seated or lying down and not only when sitting.

(ii) It is a focal akathisia, defined as the inner need to move a specific body part, in this case the leg. When symptoms are severe, other parts of the body may be affected, but the legs are always affected.

(iii) The symptoms are immediately stopped or relieved with movement. This differs from the other pathologies such as chronic pain syndromes or vascular compression.

(iv) The relief or symptomatic improvement persists as long as the movement is continued, returning as soon as the individual interrupt it.

(v) There is usually a time of day when RLS symptoms are not present or are less intense. In this period of the day, the individual may remain more time sitting or lying down, before symptoms occur. The circadian pattern of RLS is such that the patient usually does not experience discomfort in the morning, with exacerbation of symptoms in the afternoon and evening.

(vi) The physical examination is usually normal in RLS. No physical changes in the lower limbs, such as muscle atrophy, skin changes and phaneros changes, varices, etc.

In a recent review of drug induced RLS, all studies that evaluated induction or exacerbation of RLS were considered as level IV evidence ${ }^{29}$. The vast majority of studies did not control additional risk factors, eg, concomitant use of alcohol, tobacco or caffeine. Likewise, there was no control for concomitant use of other drugs, a common practice in patients under psychiatric treatment. In that review, the strongest evidence regarding RLS induced or exacerbated by drugs was related to use of escitalopram, fluoxetine, levodopa-carbidopa and pergolide (augmentation), levothyroxine, mianserin, mirtazapine, olanzapine and tramadol (augmentation). 


\section{COMPLEMENTARY TESTS}

The selection of laboratory tests should be performed according to the clinical suspicion (as primary or secondary).

Primary form:

- $\mathrm{CBC}$, ferritin, transferrin total saturation (CONSENSUS).

Secondary forms:

- $\mathrm{CBC}$, ferritin, transferrin total saturation;

- Additional laboratory tests according to clinical suspicion of underlying pathology (eg, urea, glucose, TSH, liver enzymes) (CONSENSUS).

Ferritin values below $50 \mathrm{mg} / \mathrm{l}$ are associated with increased risk of RLS, even in patients with normal hemoglobin, with greater severity of symptoms and decreased sleep efficiency. Thus, the assessment of serum ferritin is recommended in all patients with $\mathrm{RLS}^{30,31}$.

\section{ROLE OF THE PSG TEST IN THE EVALUATION OF RLS}

The diagnosis of RLS is essentially clinical, based on the diagnostic criteria previously mentioned. Therefore, the PSG is not necessary for diagnosis. However, in situations where the clinical diagnosis is doubtful, the PSG provides additional resources, since about $80 \%$ of RLS patients have PLMS $^{32}$. The PLMs are described as rhythmic hallux extensions with the heel dorsiflexion and occasional bending of the knee and hip joint, occurring during sleep or wakefulness, with a tendency to concentrate during NREM sleep, in series at regular intervals.

Patients with low intensity symptoms, persistence of symptoms despite treatment and possible sleep disordered breathing are examples of situations in which the PSG can be useful in the management of RLS ${ }^{33}$. Polysomnography findings in RLS may include, in addition to increasing rate of periodic movements of the lower limbs, increased sleep latency, sleep fragmentation, reduced total sleep time and reduction of slow wave sleep ${ }^{10,12}$.

\section{OTHER METHODS OF ASSESSMENT}

The actigraphy with accelerometer, portable device capable of detecting body movements, has no well established role in the routine clinical evaluation of patients with RLS. Therefore we do not recommend the use of actigraphy in the diagnosis, assessment of disease severity, or therapeutic indication. However, actigraphy may be considered for evaluating the therapeutic effects according to the recommendations of $\mathrm{AASM}^{34}$.

The suggested immobilization test (SIT) records surface electromyography with electrodes placement on the tibialis anterior muscles during immobilization at night. This test aims, through the reproduction of the conditions related to the onset of symptoms, change the clinical manifestations into objective measures. This is achieved through a questionnaire and measurement of periodic limb movements occurring during wakefulness (PLMW). With this test we can see that PLMW are significantly more frequent in patients with RLS than in patients with PLMD connected to other causes. The test may represent a diagnostic aid and provide an objective measure to therapeutic control ${ }^{35}$.

\section{CARDIOVASCULAR CONSEQUENCES}

Studies suggesting cardiovascular changes in RLS are recent. The reduction in total sleep time caused by the syndrome and the association with the PLMs may suggest that an increase in sympathetic activity and even increased insulin resistance may occur in the long term. However, RLS is also more frequent in patients with renal, hepatic, neurological and reumatic diseases ${ }^{36,37}$, and may even increase cardiovascular risk in these patients ${ }^{38,39}$.

Population-based cross-sectional studies have suggested an association between cardiovascular disease and RLS. Ulfberg and $\mathrm{cols}^{40}$ showed that men who had RLS reported greater presence of heart disease $(\mathrm{OR}=2.5,95 \% \mathrm{CI} 1.4-4.3)$ and hypertension $(\mathrm{OR}=1.5,95 \% \mathrm{CI}$ 0.9-2.4). Ohayon \& Roth $^{41}$ found 1.36 (95\%CI 1.14-1.61, $\mathrm{p}<0.001$ ) risk for hypertension of and 1.41 for coronary heart disease (95\%CI 1.06-1.88, $\mathrm{p}<0.05$ ), after adjusting for confounding variables.

Cohort studies, Wisconsin Sleep Cohort and Sleep Heart Health Study, both found more reports of cardiovascular disease among people with RLS, especially with daily symptoms $(\mathrm{OR}=2.58,95 \% \mathrm{CI}$ 1.38-4.84). In the Sleep Heart Health Study they found 2 times higher chance of having coronary heart disease or cardiovascular disease even after adjustment for age, gender, ethnicity, BMI, diabetes mellitus, systolic blood pressure, use of antihypertensive medication, cholesterol and smoking history. The risk was higher in patients with more frequent symptoms, occuring more than 16 times per month ${ }^{42,43}$.

In a more recent study with 65,544 women (41-58 years old), the adjusted odds for hypertension in women with RLS symptoms over 15 times per month was 1.41 (95\%CI 1.24-1.61) compared to those without symptoms $(\mathrm{p}<0.0001)^{44}$. In the Women's Health Study, no association was found between the presence of RLS and cardiovascular events $^{45}$. Only after regression analysis models, the study showed a weak association of RLS with BMI $\geq 35 \mathrm{~kg} / \mathrm{m}^{2}$ $(\mathrm{OR}=1.35,95 \% \mathrm{CI} 1: 17$ to $1: 56)$, diabetes $(\mathrm{OR}=1.19,95 \% \mathrm{CI}$ 1:04 to 1:35), dyslipidemia ( $\mathrm{OR}=1.17,95 \% \mathrm{CI} 1: 09$ to $1: 26$ ), smoking $(\mathrm{OR} \geq 15$ cigarettes $/$ day $=1.41,95 \% \mathrm{CI} 1.19-1.66)$ and the physical activity (OR for $\geq$ exercises $4 \mathrm{x} /$ week $=0.84$; 95\%CI 0.74-0.95). 
Regarding prospective studies, one evaluated 70,977 women (average age 67 y.o) initially without coronary heart disease or stroke, from 2002-2008. Women with RLS lasting three years or more had a higher chance of coronary heart disease (defined as fatal or non- fatal myocardial infarction), with hazard ratios of $1.72(95 \% \mathrm{CI} 1.09-2.73, \mathrm{p}=0.03)^{46}$. Two other studies have evaluated health professionals $(29,756$ women aged 45 or more and 19,182 men aged 40 years or more). The authors found no increased risk for cardiovascular events with and without the exclusion of participants with comorbidities ${ }^{47}$.

Finally, with regard to mortality, there were reports of increased risk (hazard ratio $=1.85,95 \%$ CI 1.20-2.85, $\mathrm{p}=0.005$ ) in women with RLS and daytime sleepiness after follow-up of 20 years ${ }^{48}$. Other prospective studies, also cohort, with followup from 6 to 11 years, found no increase in mortality for all causes $^{49}$.

From the standpoint of clinical disease to the risk of RLS, Winter et al. ${ }^{50}$ found that the presence of diabetes significantly increased chance of RLS in men $(\mathrm{OR}=1.41,95 \% \mathrm{CI}$ 1.21 to 1.65$) \mathrm{n}=22,786$ with an average age of 67.8 years old.

In summary, the literature suggests increased cardiovascular risk in patients with RLS associated with the severity and frequency of symptoms. But a causal relationship can not yet be established, since there are few prospective studies and with appropriate design.

\section{RECOMMENDATION}

Patients with restless legs syndrome should be screened and treated for cardiovascular risk factors (level B of evidence).

\section{CONSIDERATIONS ON THE USE OF LEVODOPA IN THE TREATMENT OF RESTLESS LEGS SYNDROME}

Levodopa is effective, in the short term, to treat Restless Legs Syndrome (RLS), improving symptoms, quality of sleep and quality of life (Class 1 , level B) ${ }^{52}$. However, dopamine agonists are superior to levodopa in improving symptoms related to quality of life and sleep duration ${ }^{52}$.

The use of levodopa can be more advantageous than other therapies for patients with intermittent symptoms of RLS not requiring daily treatment (using "as needed") ${ }^{51}$. The tolerability of levodopa is greater than that of cabergoline, but evidence to the long term treatment is limited ${ }^{3}$. In addition, levodopa is at greater risk of augmentation than the dopamine agonists, pramipexole and cabergolina ${ }^{51}$.

It should be noted that the recommendation of levodopa/ benserazide changed compared to the previous criteria, ceasing to be "standard" (default) and rising to level of recommendation "guideline" - is not standard but is eligible, high level of evidence, approved "off-label" by the FDA (not prohibited but not recommended), balanced risk benefit especially for occasional use (this means that the benefits do not outweigh the risks much difference).

\section{TREATMENT WITH DOPAMINE AGONISTS (DA)}

Dopamine agonists are the most studied agents used to treat RLS. The largest quantity and quality of clinical studies has led to an increasing body of scientific evidence regarding the use of these drugs. These dopaminergic agents may be divided into two groups: non-ergot and ergot derivatives. The non-ergots available in Brazil are pramipexole and piribedil. The ergots are pergolide, lisuride and bromocriptine.

After a survey in Cochrane databases, MEDLINE, EMBASE, PsycINFO, and www.clinicaltrials.gov and www.clinicalstudyresults.org, it were found 15 randomized controlled trials investigating the use of dopamine agonists versus placebo in the treatment of moderate to severe RLS (considering the available drugs in Brazil). In most studies, the diagnostic criteria for RLS followed ICSD-2 (International Classification of Sleep Disorders) or the IRLS (International RLS Study Group) (Table 1).

\section{MAJOR NON-ERGOT DA}

\section{Pramipexole}

Pramipexole is an agonist of D1, D2 and D3 dopaminergic receptors, with greater affinity for D3. It is the most studied (see major studies in Table 4). We found 8 studies (Table 5) with evidence level $1 \mathrm{~A}$ for their short-term efficacy (up to 12 weeks) and 3 other long-term studies (up to one year) revealing persistent effect in more than $80 \%$ of patients ${ }^{53,54,55}$. All the studies have shown improvement in symptoms as assessed by tools and questionnaires. The available presentations are tablets of $0.125 / 0.25 / 0.5 / 0.75 / 1.0$ and $1.5 \mathrm{mg}$ or extended-release tablets of 0.375 / 0.75 / 1.5 / 3.0 and $4.5 \mathrm{mg}$. The half-life is 8 to 12 hours and the onset of action of 1-2 $\mathrm{h}$ after ingestion. The recommended initial dose is $0.125 \mathrm{mg}$, two hours before the onset of symptoms, but we may gradually titrate the dose and/or schedule according to the therapeutic response.

Implications for clinical practice: grade A recommendation for the treatment of moderate to severe RLS, based on evidence level $1 \mathrm{~A}$.

\section{Piribedil}

Piribedil is an agonist of dopamine D2/D3 receptor and alpha-2 adrenergic antagonist. This drug is used sporadically to treat disorders of vascular vestibular-cochlear origin and 
Table 5. Randomized, double-blind, placebo-controlled studies with dopamine agonists (available in Brazil) in RLS treatment.

\begin{tabular}{|c|c|c|c|c|c|}
\hline Agent & Study & $\mathrm{N}$ & Duration & Dose* (mg) & Parameter \\
\hline \multirow[t]{8}{*}{ Pramipexole } & Ferini-Strambi et al., $2008^{18}$ & 357 & 12 weeks & 0.75 & IRLS, QoL, MOS \\
\hline & Inoue et al., $2010^{19}$ & 41 & 6 weeks & 0.75 & IRLS, MPM, PGI, CGI, PSQI \\
\hline & Montagna et al., $2011^{20}$ & 402 & 12 weeks & 0.75 & IRLS \\
\hline & Montplaisir et al., $1999^{21}$ & 10 & 4 weeks & 1.5 & MPM, AS \\
\hline & Oertel et al., $2007^{22}$ & 338 & 6 weeks & 0.75 & IRLS, CGI, PGI \\
\hline & Partinen et al., $2006^{23}$ & 86 & 3 weeks & 0.75 & IRLS, CGI \\
\hline & Winkelman et al., $2006^{24}$ & 339 & 12 weeks & 0.75 & IRLS, CGI, QoL \\
\hline & BI 248.616, $2008^{25}$ & 376 & 6 weeks & 0.25 & IRLS, CGI, PGI \\
\hline \multirow[t]{4}{*}{ Pergolide } & Earley et al., $1998^{26}$ & 16 & 18 days & 0.65 & MPM, ES, SA \\
\hline & Pieta et al., $1998^{27}$ & 8 & 10 days & 2.5 & PLM, SE, SA \\
\hline & Trenkwalder et al., $2004^{11}$ & 83 & 48 weeks & 0.75 & IRLS, PLM, SE, PGI \\
\hline & Wetter et al. $1999^{28}$ & 28 & 4 weeks & 0.75 & MPM, TTS, AS \\
\hline Bromocriptine & Walters et al., $1988^{29}$ & 6 & 4 weeks & 7.5 & SA, PLM, TST \\
\hline \multirow[t]{2}{*}{ Lisuride } & Benes et al., $2005^{14}$ & 153 & 12 weeks & 10 mg/48h & IRLS, CGI, MPM \\
\hline & Benes et al., $2008^{17}$ & 231 & 12 weeks & $7.5 \mathrm{mg} / 48 \mathrm{~h} * \star$ & IRLS, CGI, PLM \\
\hline \multirow[t]{3}{*}{ Cabergoline } & Stiasny-Kolster et al., $2004^{30}$ & 80 & 5 weeks & $0.5-2$ & IRLS \\
\hline & Oertel et al., $2006^{31}$ & 43 & 5 weeks & 2.0 & IRLS, PLM, QoL \\
\hline & Trenkwalder et al., $2007^{32}$ & 204 & 30 weeks & $2-3^{\# \#}$ & IRLS, CGI, QoL \\
\hline
\end{tabular}

*In most of the studies there was a gradual dose increase beginning with the minimal doses; **Comparative study with Ropinirole 3.0 mg. "Parâmetros que refletiram redução dos sintomas de SPI quando comparados ao placebo ou outra droga; \#\#Comparative study with levodopa/bezerasida 200/50. IRLS: International Scale Severity of the International Restless Legs Syndrome study group; SA: Subjective avaliation; PGI: Patient Global Impression; CGI: Clinical Global Impression; QoL: escala visual de qualidade de vida; TSL: Total sleep time; PLM: Periodic limb movement; SE: Sleep efficiency; MOS: medical outcome scale; PSQI: Pittsburgh Sleep Questionary Index.

other vasculopathies. The drug reaches its maximum plasma concentration one hour after oral administration and is biphasic, with plasma elimination half-life of 1.7 to 6,9 hours. In a pilot study involving 13 patients it was observed a subjective improvement of nighttime symptoms of RLS in 11 participantes ${ }^{56}$. There are no randomized placebo-controlled trials.

Implications for clinical practice: recommendation grade $B$ based on the existence of one study with level of evidence 2C. Therefore piribedil is considered possibly effective in the treatment of moderarte to severe RLS and is recommended as a treatment option but not as an initial treatment.

\section{Ropinirole}

Ropinirole is a dopamine agonist that acts mainly in the D2 and D3 receptors with higher affinity to D3. Presentations are tablets of $0.25,0.5,1.0,2.0$ and $5.0 \mathrm{mg}$. Ropinirole reaches its maximum plasma concentration between 1 and 2 hours after oral administration and has a half life of 6 hours. It is not yet available in Brazil. Along with pramipexole, ropinirole is recommended for the treatment of RLS by American and European consensus with the same degree of recommendation (A) and level of evidence (1A). This recommendation is endorsed by at least seven randomized, placebo controlled double blind trials ${ }^{51,57}$.

Implications for clinical practice: grade A recommendation for the treatment of moderate to severe RLS, based on evidence level $1 \mathrm{~A}$.

\section{Rotigotine}

Rotigotine is also not yet available in Brazil. It is D1, D2, D3, D4 and D5 agonist plus $5 \mathrm{HT}_{1 \mathrm{~A}}$ agonist and alpha2 adrenergic. The transdermal $1 \mathrm{mg}$ presentation is to be applied once a day whereas the most studied for SPI were 2 to $4 \mathrm{mg}$. The drug has been studied in five randomized, double blind, placebo controlled trials, lasting between one week and six months. The efficacy of rotigotine was superior to placebo in all parameters evaluated (IRLS, CGI, MPM and QoL).

Implications for clinical practice: grade A recommendation for the treatment of moderate to severe RLS, based on evidence level $1 \mathrm{~A}$.

\section{Adverse effects related to non-ergot DA}

These drugs are generally well tolerated in the treatment of RLS, possibly by the use of lower doses and lower prevalence of comorbidities when comparing SPI to Parkinson's disease, for example. The rare adverse effects are from weak to moderate intensity and typical for nonergot $\mathrm{AD}$ : dopamine dysregulation syndrome (disorders of addiction and impulse control), nausea, headache, somnolence, orthostatic hypotension, mental confusion, agitation, hallucinations and nasopharyngitis. These effects were reported by $23 \%$ of patients and are usually solved with drug withdrawal or reduction of dose $\mathrm{e}^{58,59,60,61}$. With regard to augmentation, there is a special session for that matter later on this article. However it should be noted that the evidences point to an incidence of up to $30 \%$ with the use of pramipexole in three years, up to $3 \%$ in 6 months of ropinirole and $13.2 \%$ up to 5 years with rotigotina ${ }^{57}$. Assessment of augmentation depends on long-term inquiry. 


\section{MAJOR DA ERGOT}

\section{Pergolide}

Pergolide is an ergolinic dopaminergic agonist with higher affinity for D1 and D2 receptors. It still exerts a serotoninergic effect on $5 \mathrm{HT}_{1 \mathrm{~A}}, 5 \mathrm{HT}_{1 \mathrm{~B}}, 5 \mathrm{HT}_{2 \mathrm{~A}}$, and $5 \mathrm{HT}_{2 \mathrm{~B}} 5 \mathrm{HT}_{2 \mathrm{C}}$ receptors. It is available in tablets of $0.05 / 0.25$ and $1.0 \mathrm{mg}$.

Currently, four randomized placebo-controlled, double blind trials show superior efficacy of pergolide to placebo in containing the symptoms of RLS (Table 1). A long-term study revealed no serious adverse effects of pergolide, over 48 weeks, at doses from 0.5 to $0.75 \mathrm{mg}^{62}$. However, although effective in the treatment of RLS, pergolide was withdrawn from the U.S. market due to the risk of cardiac valvulopathy (derived from the experience over use of ergot in the treatment of Parkinson's disease and prolactinomas and endorsed by study recente ${ }^{63}$.

Implications for clinical practice: due to the side effect profile, pergolide is considered effective but not recommended as initial treatment of RLS (grade A recommendation supported by evidence level 1A).

\section{Bromocriptine}

Ergolinic dopamine agonist with action at D1 and D2 (greater affinity for $\mathrm{D} 2)$ and serotonin $\left(5-\mathrm{HT}_{2 \mathrm{~B}}\right)$ and adrenergic weak effects. The peak plasma concentration occurs approximately 70 minutes after oral administraçãoo and its elimination half-life is 6-8 hours. The available presentations are in tablets of 2.5 and $5.0 \mathrm{mg}$. Like other ergot DA, its use in Parkinson's disease and prolactinoma was associated with increased incidence of serious complications such as valvular fibrosis cardíaca ${ }^{64}$.

Implications for clinical practice: due to the side effect profile and lack of data endorsing its effectiveness, bromocriptine is considered probably effective in the short term, but is not recommended as a treatment of RLS (grade A recommendation with level of evidence 1B).

\section{Lisuride}

Lisuride is an ergolinic dopamine D2, D3 and D4 agonist receptor, beyond agonist serotonin $5 \mathrm{HT}_{1 \mathrm{~A}}$ and $5 \mathrm{HT}_{2 \mathrm{~A}}$ serotonin agonist and $5 \mathrm{HT}_{2 \mathrm{~B}}$ antagonist. It reaches maximum plasma concentration from 1.1 to 1.3 hours after oral administration and has a half-life of one to three hours. A randomized study of 153 patients using transdermal lisuride to severe RLS showed significant improvement on PLM index, CGI-I and IRLS ${ }^{65}$. Reviewing the literature, Hofmann and colleagues justify the lower tendency to fibrotic disease associated with the use of lisuride to $5 \mathrm{HT}_{2 \mathrm{~B}}$ serotonine antagonism ${ }^{66}$. It was was estimated that in 360,000 patients studied none has shown cardiac fibrosis with rare cases of other types of fibrosis. This medication is available in $0,2 \mathrm{mg}$ tablets $^{66}$.
Implications for clinical practice: due to the side effect profile lisuride is considered effective but not recommended as a treatment of RLS (grade A recommendation, level of evidence $1 \mathrm{~A}$ - studies with transdermal presentation, not available in Brazil).

\section{Cabergoline}

Ergolinic DA preferential for $\mathrm{D} 2$ and $5 \mathrm{HT}_{2 \mathrm{~B}}$ agonist. Its main distinguishing feature is a long half life, around 65 hours. Onset of action occurs about three hours after oral intake. The presentation is in $0.5 \mathrm{mg}$ tablet. To date three randomized placebo controlled, double blind trials show efficacy of cabergoline over placebo and levodopa in controlling the symptoms of RLS although levodopa was better tolerated than cabergolida (Table 5).

Implications for clinical practice: due to the side effect profile, cabergoline is considered effective but not recommended as initial treatment for RLS, unless failure on therapy with drugs with better safety profile occurs (Grade A recommendation supported by evidence level $1 \mathrm{~A}$ ).

\section{Adverse effects related to ergot DA}

The same as the other DA, but with lower incidence ${ }^{67}$. However, it should be noted the risk for cardiac valvular, lung, pleural, pericardial and retroperitoneal fibrosis.

Despite proven efficacy in controlling symptoms of RLS and the low incidence of augmentation, ergot DA are not recommended as first choice treatment of RLS due to the risk of serious side effects, mainly fibrotic disease and shoul be avoided.

In summary, with regard to the treatment of RLS with dopaminergic agonists, although it is a traditional practice, there is still a paucity of studies describing the safety and long-term efficacy of these drugs in patients with RLS (median duration of clinical trials known is 10 weeks, ranging from 1 to 30 weeks). Furthermore, in general, the therapeutic effects between the various treatment options for RLS have not been compared, except the few studies comparing the effectiveness between different dopamine agonists which showed greater efficacy of ergolínics ${ }^{67}$. Another demand is a specific approach to augmentation related to these drugs.

Based on the information presented above, the recommendations of the Brazilian experts on the treatment of RLS with dopaminergic agonists are summarized in Table 6 .

\section{ALPHA DELTA LIGANDS AGENTS}

\section{Gabapentin}

Gabapentin is an agonist $\alpha 2 \delta$-1 subunit complex calcium channel voltage-dependent present on neurons, for orally exclusive use. Gabapentin is traditionally used to treat epilepsy and neuropathic pain. The presentations in the 
domestic market are with 300, 400 and $600 \mathrm{mg}$ tablets and $400 \mathrm{mg}$ and 300 capsules. The maximum recommended dose for adults is $3600 \mathrm{mg}$ per day, divided into 3-4 doses, and the use should be recommended for patients older than 12 years of age. The most prevalent side effects are drowsiness, dizziness, fatigue, headache, and tremor.

However, gabapentin has been used in the treatment of RLS with therapeutic action confirmed in a few studies, and is considered the first non-dopaminergic agent that failed to demonstrate efficacy in the treatment of RLS. There are only two controlled studies on gabapentin as used in Brazil. The first study demonstrated its superiority over placebo $^{68}$, and the second study with only 8 patients demonstrated efficacy when gabapentin was compared with ropinirole ${ }^{69}$.

The review of articles with quality criteria to assess the action of gabapentin in the treatment of RLS in patients with chronic renal failure showed only two articles. Thorp and colleagues demonstrated the benefit of the use of gabapentin in a crossing over type study with 16 chronic renal patients using doses ranging from 200 to $300 \mathrm{mg}$ to day $^{70}$. Micozkadioglu and collaborators showed improvement of RLS symptoms in 15 patients on hemodialysis after gabapentin at doses of 125 to $200 \mathrm{mg} / \mathrm{day}^{71}$.

The positive results in the symptoms of RLS give Gabapentin Class I recommendation for use, but with level of evidence B due to the limited number of studies in general populations and chronic renal failure.

\section{Pregabalin}

Pregabalin is an agonist $\alpha 2 \delta-1$ subunit complex calcium channel voltage-dependent present in neurons, for exclusive use by oral administration. Pregabalin is traditionally used for the treatment of epilepsy, neuropathic pain, fibromyalgia and generalized anxiety disorder. The presentations in the domestic market are tablets of 75 and $150 \mathrm{mg}$. The maximum recommended dose for adults is $600 \mathrm{mg}$ daily, usually divided into two doses, with the recommended use in patients older than 12 years of age. The most prevalent side effects are drowsiness and dizziness.

Pregabalin has also been studied in recent years to treat RLS with more robust results than gabapentin. Two studies demonstrated that pregabalin can be used safely.

Table 6. Dopaminergic agonists for restless legs syndrome treatment (available in Brazil).

\begin{tabular}{lc} 
Drug & Recommended \\
\hline Pramipexole & Recommended \\
Piribedil & Optional \\
Bromocriptine & Contraindicated \\
Cabergoline & Optional \\
Pergolide & Contraindicated \\
Lisuride & Optional \\
\hline
\end{tabular}

The first study was carried out with 6 weeks duration in a group of RLS patients classified as moderate to severe. These patients were divided into 6 groups to analyze the effectiveness of the medication and the most appropriate dose in $\mathrm{mg}$ (50/100/150/300/450) and 114 patients using pregabalin versus 23 patients on placebo. As a result, the authors demonstrated symptoms reduction from $123.9 \mathrm{mg}$ dose, i.e. only doses greater than or equal to $150 \mathrm{mg}$ were eficacious ${ }^{72}$. Side effects were also dose dependent, the most common being dizziness and drowsiness followed by dry mouth, fatigue, headache, abnormal dreams ${ }^{72}$.

The second study, a case control lasting 12 weeks, showed improvement with a dose of $300 \mathrm{mg}$, where 30 patients with idiopathic RLS were compared with 28 controls. There was an improvement of RLS symptoms, improvement in sleep architecture and reduction of periodic limb movements ${ }^{73}$. In this study, gait instability was the most frequently observed side effect followed by drowsiness. Other side effects observed were headache, blurred vision, dizziness, dry mouth, dyslalia allergic rash and nausea. There are no studies comparing pregabalin with other drugs for RLS.

The search for articles with quality criteria for assessing the effect of pregabalin in the treatment of RLS in patients with peripheral neuropathy showed only one article. Sommer and colleagues demonstrated the benefit of using prebagalin in 16 patients with neuropathic pain at doses between 150 and $600 \mathrm{mg}$ a day ${ }^{74}$.

Pregabalin treatment also resulted in improvement in symptoms of RLS patients, receiving Class I recommendation for its use, but level of evidence B for general populations and patients with neuropathic pain (Table 7).

\section{TREATMENT OF RLS BY OPIOID AGENTS}

For several decades, opioids have been used empirically as an alternative for the treatment of RLS. There are no Class I studies on the treatment of Restless Legs Syndrome by opioids. A Class II study indicates that oxycodone is probably effective in the pharmacological treatment of $\mathrm{RLS}^{75}$. A Class II study evaluated the drug propoxyphene. However, the outcomes were periodic leg movements and measures of sleep quality, without a direct assessment of RLS symptoms ${ }^{76}$. For other opioids (codeine, methadone, tramadol and others) there are only studies of Classes III and $\mathrm{IV}^{77,78,79,80}$. Some of these studies report mainly on the tolerability of opioids in the long term, providing only indirect data $^{80}$ or no information on clinical effectiveness ${ }^{101}$. The data that draws attention in studies of Ondo and Silver ${ }^{79,80}$ is that all patients who abandoned treatment with opioids (around $15 \%$ in total), did it in the first year of treatment, with no dropouts from the second year. In a retrospective study of 
Table 7. Alpha delta ligants drugs and level of evidence.

\begin{tabular}{|c|c|c|c|c|}
\hline Treatment & Selected articles & Number of patients/controls & Doses (mg) & Recomendations \\
\hline \multirow[t]{3}{*}{ Gabapentin } & 2 & $30 / 22$ & $300-2,400$ & I B \\
\hline & Garcia-Borreguero D et al., 2002 & $22 / 22$ & $600-2,400$ & \\
\hline & Svenja H, et al., 2003 & $8 / 0$ & 300 & \\
\hline \multirow[t]{3}{*}{ Gabapentin (IRC) } & 2 & $31 / 16$ & $125-300$ & I B \\
\hline & Thorp ML et al., 2001 & $16 / 16$ & $200-300$ & \\
\hline & Micozkadioglu H et al., 2004 & $15 / 0$ & $125-200$ & \\
\hline \multirow[t]{3}{*}{ Pregabalin } & 3 & $144 / 51$ & $50-450$ & I B \\
\hline & Allen R et al., 2010 & $114 / 23$ & $50-450$ & \\
\hline & Garcia-Borreguero D et al., 2010 & $30 / 28$ & $150-450$ & \\
\hline \multirow[t]{2}{*}{ Pregabalin (neuropathy) } & 1 & $16 / 0$ & $150-600$ & I B \\
\hline & Sommer M et al., 2007 & $16 / 0$ & $150-600$ & \\
\hline
\end{tabular}

29 patients using methadone after failed treatment with dopaminergic agents, $63 \%$ of patients were still on methadone after $23 \pm 12$ months of treatment, all reporting a reduction of at least $75 \%$ of symptoms without augmentation.

All these studies, coupled with clinical experience suggests that opioids are particularly useful for patients with refractory forms of RLS and/or development of augmentation when treated with other agents, or for use as needed in patients with intermitent symptoms ${ }^{51,81}$. Pharmacological efficacy of opioids seems to be specifically related to Mu type, as opposed to Kappa type opioid receptor agonism, which has practical implications for drug choice ${ }^{79}$. Moreover, effectiveness of opioid therapy seems to depend, in some way, on interaction with dopaminergic transmission ${ }^{79}$.

The average recommended oxycodone dose is $10 \mathrm{mg}$ (ranging from 5 to $20 \mathrm{mg}$ ) administered as a single dose 2 hours before the usual onset of symptoms ${ }^{75}$. For tramadol the recommended dose is $50-400 \mathrm{mg}^{77,81}$ and for methadone $5-40 \mathrm{mg}^{79,80}$.

The most common side effects are: constipation, sedation, a possible risk for the development or worsening of sleep breathing disorders ${ }^{78}$ and a non-defined potential for abuse in predisposed patient. Therefore, patients should be clinically monitored for these symptoms. In general, however, these drugs are well tolerated ${ }^{51}$. There is a case report of augmentation with long term use of tramadol ${ }^{82}$. Another study reported lower risk of augmentation with methadone than with long term use of dopaminergic agents ${ }^{82}$ (Tables 8 and 9).

\section{IRON IN THE TREATMENT OF RLS}

Although there are data suggesting that iron is associated with the pathophysiology of RLS and various data in the literature reporting the benefits of replacing oral or parenteral iron in patients with RLS, there are no good-quality studies that give scientific support decisions about their effectiveness and safety. In summary, the studies do not allow us to say whether the oral or parenteral iron is beneficial to patients with RLS.

A Cochrane systematic review ${ }^{83}$ is the best synthesis of knowledge about available iron and SPI. The authors concluded that there is no clear evidence of the role of iron in the treatment of RLS. The primary studies did not support or not to recommend the use of iron in the treatment of this disease. An important aspect is that the adverse effect was not different between the study groups and placebo.

The systematic review allowed the identification of two studies using the primary route iron ${ }^{84,85}$ and four primary studies that used intravenous iron ${ }^{86,87,88,89}$. The use of iron led to a reduction of 3.8 points in RLS Severity Scale, and dopaminergic agonists reduce an average of 5.7 points. The effect appears to be discreet, but the studies presented other problems such as sample size, dose, and length of follow-up. A recommendation for all studies is to avoid the intravenous formulations of high molecular weight, such as iron dextran. The formulations of iron sucrose, and iron-saccharate carboxymaltose have low molecular weight. The iron-saccharate (hidroxisaccharate iron III) is available in Brazil.

The oral iron used in the two studies was ferrous sulfate at a dose of $325 \mathrm{mg}$ two times a day.The intravenous iron was used in different ways. One study employed $30 \mathrm{mg}$ IV iron to test and after 1 hour if no adverse reaction occurred, plus $970 \mathrm{mg}$ was infused over 3 hours. Another study used two doses of $500 \mathrm{mg}$ of iron (ferric carboxymaltose) diluted in $100 \mathrm{ml}$ saline, both applications being spaced 5 days. Another way to use the intravenous iron was $200 \mathrm{mg}$ iron sucrose repeated five times over 3 weeks.

The conclusion of this consensus on the use of iron in the treatment of RLS is that there is no robust evidence to indicate or contraindication of their use. Thus, the use of iron in the treatment of RLS should be decided by the physician involved in patient care, considering the studies currently available. The patient should be informed about the side effects and possible benefit unrepresentative. 
Table 8. Original individual studies and level of evidence for opioids.

\begin{tabular}{|c|c|c|c|c|}
\hline Treatment & Original articles & n pat/control & Total dose (mg) & Recomendation \\
\hline & Lauerma H \& Markkula J., 1999 & 12 & Tramadol (50-150) & III C \\
\hline & Walters A et al., 1993 & 11 (x-over) & Oxycodone $(5-20)$ & $\| B$ \\
\hline & Walters A et al., 2001* & $36 / 0$ & $\begin{array}{l}\text { Codeíne }(30-120) \text { Di-hidrocodeíne }(60-240) \\
\text { Methadone (10-40) Oxycodone }(5-20) \\
\text { Tilidine (25-100) Propoxyphene }(65-260)\end{array}$ & IV C \\
\hline & Ondo WO, 2005 & $27 / 0$ & Methadone $(5-40)$ & IV C \\
\hline & Silver et al., 2011* & $76 / 0$ & Methadone (5-40) & IV C \\
\hline
\end{tabular}

x-over; *Outcomes of tolerability and not efficacy.

\section{OTHER TREATMENTS}

On the role of other drugs and non-pharmacological treatment of RLS, the information available comes from isolated studies with short term follow-up and, mostly, with very few patients. The data indicate that drugs such as carbamazepine, clonidine and sodium valproate are likely to be effective while valerian and bupropion are ineffective, but the level of evidence for this evaluation is low. Are even more limited and thus insufficient evidence concerning the use of clonazepam, botulinum toxin and non-pharmacological measures. Data on drugs and methods evaluated by at least one randomized controlled study are described below (level of evidence $2 \mathrm{~b}$ ).

\section{TREATMENT WITH OTHER DRUGS}

\section{Carbamazepine}

There is a large randomized, placebo-controlled, double blind trial that showed significant improvement in the frequency and severity of RLS symptoms after 3 and 5 weeks of administration of carbamazepine 100 to $300 \mathrm{mg}$ at bedtime $^{90}$. About $40 \%$ of patients and $23 \%$ of controls reported side effects, but there were no serious reactions. Another randomized, placebo-controlled study evaluated only 6 patients and demonstrated benefits in the frequency and intensity of demonstrations at a dose of $600 \mathrm{mg}$ daily ${ }^{91}$.
The two studies dating from the 80 s and used subjective measures for assessing clinical improvement.

\section{Sodium valproate}

A randomized, placebo-controlled, double-blind and cross-over trial compared $600 \mathrm{mg}$ sodium valproate (VPA) to $200 \mathrm{mg}$ levodopa, both in slow release formulations, in the treatment of 20 patients with idiopathic RLS, symptoms daily for the past six months and PLM index greater than $10 / \mathrm{h}^{92}$. After three weeks of treatment with VPA it was observed decrease in the intensity and duration of symptoms and reduction of sleep latency, but no change in PLM índex or other PSG parameters. Adverse events were reported by $45 \%$ of patients when on placebo, $45 \%$ of patients when using VPA and $65 \%$ when levodopa, but not severe reactions were observed and no patient had to discontinue the use of medication. At the end of the study, 13 patients remained using VPA and, after 18 months, effectiveness remained in $75 \%$ of patients ${ }^{92}$.

\section{Clonazepam}

Two small randomized, double-blind controlled, crossover studies evaluated the effect of clonazepam in RLS symptoms: in 6 patients $0.5 \mathrm{mg}$ at bedtime for 4 weeks showed no significant improvement in Clinical Global Impression scales of improvement ${ }^{93}$; while in another study, also with 6 patients, $1 \mathrm{mg}$ at bedtime for 3 weeks promoted

Table 9. Opioids: recomended doses and side effects.

\begin{tabular}{lrr}
\hline Opioids & $\begin{array}{c}\text { Total dose }(\mathrm{mg}) \\
1-4 \mathrm{x} \text { day }\end{array}$ & Adverse effects \\
\hline Codeine & $30-120^{4}$ & \\
Di-hidrocodeine & $60-240^{4}$ & \\
Metadone & $5-40^{5,6}$ & constipation, sedation, possible risk for development or worsening of sleep respiratory disturbances, \\
Oxicodone & $5-20^{3,4}$ & risk of abuse in predisposed patients ${ }^{4}$ (lower risk of augmentation than dopaminergic agents ${ }^{6,7}$ ). \\
Propoxifen & $65-260^{4}$ & \\
Tilidine & $25-100^{4}$ & \\
Tramadol & $50-150^{1}$ & \\
& $100-400^{2}$ & \\
\hline
\end{tabular}


subjective improvement in sleep ${ }^{94}$. A placebo-controlled, single-blind study evaluated the effect of only $1 \mathrm{mg}$ dose of clonazepam in polysomnographic parameters of 10 patients with RLS and it was observed an increase in total sleep time and sleep efficiency, reduction in the number of arousals and time awake after sleep onset, with no change in the rates of periodic movements of members (PLM) ${ }^{95}$.

\section{Clonidine}

In a randomized, placebo-controlled, double-blind, crossover trial, $0.5 \mathrm{mg}$ of clonidine at bedtime for three weeks caused a reduction of sleep latency and improved symptoms of unpleasant sensations, motor restlessness and daytime fatigue. The side effects were frequent, but mild ${ }^{96}$.

\section{Valerian}

The effect of valerian was tested in a small randomized, placebo-controlled, double-blind study in which the intake of $800 \mathrm{mg}$ (1.16 mg of valerenic acids) 1 hour before bedtime for 8 weeks caused no significant improvement in sleep latency, in the excessive daytime sleepiness or in the severity scale of RLS $^{97}$.

\section{Bupropion}

Bupropion dose of $150 \mathrm{mg}$ administered two hours before sleep was evaluated in a randomized, placebo-controlled, double-blind study. The statistical significance of the improvement of RLS severity score observed in the first 3 weeks of use not remained after 6 weeks, and there were no differences when compared to placebo $^{98}$.

\section{Botulinum Toxin}

Intramuscular injection of botulinum toxin in 3 patients caused no significant improvement in RLS severity score after 4 weeks, compared to saline injection in a randomized, placebo-controlled, double blind study ${ }^{99}$. In an open study with 8 patients, the intramuscular injection of botulinum toxin also showed no improvement in severity score after 12 weeks, but has shown improvement in 4 weeks $^{100}$.

\section{NON-PHARMACOLOGICAL TREATMENTS}

\section{Physical exercise}

A randomized controlled study evaluated the effect of an aerobic a low-resistance exercise program 3 times a week. Significant reduction of RLS severity score was observed after 6 weeks and was maintained after 12 weeks ${ }^{101}$.

\section{Intermittent pneumatic compression}

A randomized, placebo-controlled, double-blind study of intermittent pneumatic compression 1 hour daily for 4 weeks showed a significant improvement in RLS severity score, excessive daytime sleepiness, fatigue and quality of $\operatorname{life}^{102}$.

\section{Infrared light}

In a randomized, placebo-controlled study sessions of infrared light held 3 times a week for 4 weeks promoted a significant reduction in the severity score from the second week of treatment and was maintained in all evaluations until a week after the suspension of the sessions ${ }^{103}$. In open assessment after four weeks of the closing sessions, $67 \%$ of patients reported worsening of symptoms ${ }^{126}$.

\section{Acupuncture}

According to a systematic review, there is insufficient evidence to determine whether acupuncture is effective and safe for treatment of $\mathrm{RLS}^{104}$. Among fourteen potentially relevant studies, only two met the inclusion criteria but still had methodological limitations. One showed slight but significant improvement in the frequency and intensity of RLS symptoms, while the other study included in the review showed no difference ${ }^{104}$.

\section{Other non-pharmacologic treatments}

A randomized, placebo-controlled study, involving only 4 patients and 2 controls, using the technique of facilitated external counterpulsation for treatment of RLS showed no reduction in the severity score ${ }^{105}$.

\section{AUGMENTATION}

Augmentation was initially described as a serious worsening of RLS symptoms in a long-term treatment with levodopa ${ }^{106}$. However, subsequent studies have shown the occurrence of augmentation with all dopamine agonists ${ }^{107}$.

Among the risk factors for the occurrence of augmentation are the use of selective serotonin reuptake inhibitors of serotonin and norepinephrine, antihistamines and chronic loss of iron, but the data are not definitive ${ }^{108}$. The state of clinical severity of RLS pre-treatment (daily or refractory forms) as well as aging are risk factors for the development of augmentation. However, gender does not represent additional risk. Likewise, there are no reports of augmentation with antiepileptic or opioids (except to tramadol) ${ }^{109}$.

Five to seven percent was the estimated incidence, according to 10 years follow-up trial performed with patients taking dopamine agonists and, in up to $35 \%$ of patients, the augmentation was responsible for the treatment discontinuation $^{106}$.

Allen and colleagues have recently shown an incidence of $8 \%$ in a poll online study using defined diagnostic criteria $^{108}$. 
The clinical definition and initial approach of Augmentation were hampered by the absence of specific clinical criteria, but the situation began to change after the meetings of experts and the determination of the criteria of the National Institutes of Health (NIH) in 2002. These criteria were subject to revaluation in the international symposium held in Munich in 2006 (Max Planck InstituteMPI), which caught the attention of the clinical significance and severity of symptoms of augmentation ${ }^{4}$.

The clinical definition of augmentation follows this order of symptoms ${ }^{108}$ :

Criterion 1: Sensory-motor symptoms occur at least 2 hours earlier than usual

Criterion 2: Two or more of the following:

- Worsening of symptoms with increasing dose and improvement with its reduction;

- Lower latency of symptoms onset after entry into resting state;

- Expansion Space (need to move extends to body regions previously unaffected). Shorter duration of dose effect in relation to starting treatment;

- Periodic limb movements arise or worsen during wakefulness arise.

\section{Attention:}

(1) Symptoms of augmentation must be present for at least 2 weeks, 5 days a week;

(2) Absence of psychiatric, behavioral, medical, pharmacological disturbances that justify the symptoms.

Rebound, tolerance and progression of RLS are phenomena that must be differentiated clinically from augmentation because of its consequences for the therapeutic decision.

Rebound (25\%) is the reappearance of symptoms and intensification after the end of dose effect.

Tolerance is the loss of therapeutic effect of a certain dose of medicament. Some authors have even claimed that the habitual use of low doses of dopaminergic agents could, in some cases, result in tolerance with loss of therapeutic efficacy, need for dose escalation and eventual favoring augmentation ${ }^{106}$. However, in general, increasing the dose leads to elimination of symptoms of tolerance, unlike what occurs in augmentation.

Progression is a slow and gradual increase in the intensity of symptoms without temporal or spatial expansion, in patients using dopamine agonists, dopamine precursors, opioids, antiepileptic drugs or other classes of medications and can represent the characteristic fluctuation that happens in this syndrome.

Clinical experience suggests approaching augmentation by defining the severity of the condition as follows ${ }^{109}$ :

(a) Interference with activities of daily living and/or behavior (stop using the car or driving in the afternoon);

(b) Negative impact on quality of life (sleep, mood); (c) Need to change treatment (increase or split doses or change the schedule);

(d) Add adjunctive or concomitant medications to SPI (analgesics, hypnotics);

(e) Other aspects considered by the physician (must be specified).

In these cases a change in the treatment regimen may be necessary. Roughly speaking, if the augmentation symptoms occur with use of dopamine agonists, the first step should be chosen initially for an advance schedule of dose and, if necessary, their reduction and division in multiple schedules. Alternatively, we can opt for the non-dopaminergic treatment with GABAergic antiepileptic drugs (gabapentin, pregabalin) or opioids. However, further studies are needed to definitively say that this change in regimen is really effective in improving augmentation symptoms or in its prevention ${ }^{132}$.

Recent studies have demonstrated the efficacy of new RLS treatments, with whom would be the lowest rate of onset or prone to the phenomenon of augmentation (rotigotine patches, gabapentin enacarbil XR) $)^{110,111}$.

Finally, it must be emphasized the efficacy of opioids, particularly methadone, not only treating the symptoms of RLS as well as reducing the symptoms of augmentation and restoring sleep ${ }^{86,109}$.

\section{SPECIAL SITUATION: RESTLESS LEGS SYNDROME IN CHILDREN}

\section{General Aspects}

Ekbom (1945) was the first to describe the symptoms and use the term Restless Legs Syndrome ${ }^{112}$. In this series of cases, Ekbom already cites the presence of the syndrome since childhood, and in 12 patients there was a report of symptoms that begun between 10 and 19 years old. After this initial description of RLS in children by Ekbom, only in the mid-90s were the first case reports and case series on pediatric RLS. In 1994, Walters et al. ${ }^{2}$ reported the cases of four children with RLS, three of the same family ${ }^{113}$.

The diagnosis of RLS remains largely clinical with the diagnostic criteria for RLS in children in uniform in 2003 by the International Study Group on Restless Legs Syndrome (IRLSSG) ${ }^{9}$.

\section{Diagnosis and epidemiology Diagnosis}

The International Study Group on Restless Legs Syndrome (IRLSSG) proposed criteria for diagnosis in 1995, which were recently reviewed ${ }^{9,114}$. Diagnostic criteria for children were also defined for ages 2 to 12 years and above 12 years of age, as proposed by IRLSSG in three levels of demand, namely, defined RLS, probable and possible RLS, as shown below. 


\section{A. Diagnostic criteria for defined RLS in children: $\left.{ }^{*}\right)$}

The child must meet all four criteria used for RLS in adults:

(i) A desire to move the legs associated with discomfort;

(ii) Relief from this feeling with the movement;

(iii) The occurrence or worsening of symptoms in the rest position;

(iv) The occurrence or worsening of symptoms in the evening;

Associated to:

The child does describe the symptoms in their own words, which must be consistent with the complaint of discomfort in the lower limbs.

Or:

I. The child meets all the criteria for RLS for adults.

Associated to:

II. Two of the three criteria for support:

(i) Sleep disturbance for age;

(ii) Biological parents or siblings show RLS;

(iii) The child has periodic leg movement índex on PSG $(\mathrm{PLM})>5 /$ hour of sleep .

B. Diagnostic Criteria for probable RLS diagnosis in children

(i) The child meets all four RLS criteria for adults, except for item \# 4, i.e the occurrence or worsening of symptoms in the evening;

(ii) The child has a biological parent or sibling with definite RLS.

Or:

(i) The child is seen presenting manifestations of lower extremity discomfort when sitting or lying down, accompanied by movements of the affected limb and discomfort has characteristics worsen with rest and inactivity, being relieved by movement and worse at night;

(ii) The child has a biological parent or sibling with definite RLS.

C. Diagnostic Criteria for possible RLS in children

(i) The child has a disorder of periodic limb movements;

(ii) The child has a biological parent or sibling with RLS, but does not meet the criteria for definite or probable RLS.

Legend: (*) The criteria used for children older than 13 years are the same as those used for adults.

The great difficulty in making the diagnosis of RLS in children is due to their lower ability in verbal language, making dificult the subjective description of symptoms, especially when children belong to younger age groups ${ }^{115}$.
Under the ICSD, the differential diagnosis should be done with positional discomfort, hípnicas myoclonus, akathisia, cramps and other sleep-related conditions that produce chronic pain, such as arthritis, peripheral vascular diseases, sports injuries secondary to trauma and sensory neuropathies. Some of these diseases can present nocturnal pains that worsen with immobility and can also be relieved with movement, but the movement of light intensity rarely eases $i^{112}$. In children, it is worth mentioning the importance of differential diagnosis with growing pains (GP).

\section{Comorbidities}

Among the major comorbidities of Pediatric RLS we have: GP, psychiatric disorders, often associated with attentiondeficit/hyperactivity disorder (ADHD).

\section{Growing Pains (GP)}

This entity is defined as a discomfort in the legs that occurs in school-age children, with diagnostic criteria suggested by Peterson in the decade of $1980^{116}$. From the 70's there were the first epidemiological studies on growing pains.

Rajaram et al. ${ }^{28}$ observed that ten children of a group of eleven, followed up with neurologist specializing in ADHD, and who had previously received a diagnosis of GP, had RLS according to the definied criteria of IRLSSG ${ }^{9}$. Thus, they reported that there may be diagnostic confusion between GP and RLS, when the adequate diagnostic criteria for both diseases are not well applied.

Walters found no consistent pattern in the descriptions of RLS and GP in childhood, even when it was not joint pain ${ }^{117}$. He described as unlikely the possibility that all RLS patients had GP and vice versa.

\section{Psychiatric disorders}

The presence of insomnia and detection of PLM disorder in children with ADHD have led to the evaluation of the possible relationship between these entities. Studies in children with ADHD have shown RLS incidence from 11.5 to $44 \%^{118}$. The presence of cognitive impairment and ADHD has been associated with RLS and PLMs in adults and children. The relationship between RLS and ADHD could occur in several ways: 1) the sleep disorder with poor quality and multiple arousals associated with PLM and RLS could lead to inattention and hyperactivity; 2) RLS and PLM could be co-morbid with ADHD; 3) RLS and PLM, and a subgroup of ADHD could share the same pathophysiological mechanisms of dopaminergic dysfunctioning or changes on iron metabolism; 4) diurnal manifestations of RLS could mimic ADHD symptoms ${ }^{118,119}$.

In a study of Walters and colleagues some children with ADHD and PLM and RLS symptoms after specific treatment for RLS and PLM, when there was an improvement of RLS 
symptoms was also observed improvement on behavior ${ }^{120}$. Genetic study suggested the possibility of linking the gene BTBD9, related to iron storage and SPI, and some subgroups of patients with $\mathrm{ADHD}^{121}$. Another study, evaluating the medical records of 374 children and adolescents with RLS showed that $64 \%$ of them had some psychiatric comorbidity: mood disorder in $29.1 \%$ of cases, ADHD in $25 \%$, anxiety in $11.5 \%$ and severe behavior in $10.9 \%^{122}$.

\section{Epidemiology}

The prevalence of RLS in children was not established until recently. However, in the series of Walters and colleagues $^{123}$, in 1996, a third of adults with RLS reported that their symptoms began before the age of 10 , and up to $40 \%$ of adults before the age of 20 .

Two studies on the prevalence of RLS performed in children found rates of $31.7 \%$ and $5.9 \%$ respectively ${ }^{124,125}$. The study by Laberge and colleagues ${ }^{125}$ in Canada, assessed the prevalence and interactions between certain sleep disorders. In total, 1,353 children aged between 6 and 16 years old, based on diagnostic criteria for RLS in adults and followed by three consecutive years, $6.1 \%$ of the sample kept the RLS symptoms uninterruptedly. There was a significant predominance of girls $(56.8 \%)$ than boys $(43.2 \%)$ and no association was found between RLS and any other type of assessed sleep disorder.

Kinkelbur, Hellwig and Hellwig evaluated, in 2003 in Germany, the frequency of RLS in patients from pediatric practices, aged between 6 and 17 years old. They used a questionnaire to evaluate the association between dysesthesia relieved by movement and worsening at night. In a group of 1,084 children and adolescents, the frequency of involvement was $1.3 \%$ and there was no gender predominance ${ }^{126}$.

Kotagal and Silber ${ }^{127}$, in 2004, reviewed the medical records of 538 children followed for four years in a pediatric sleep service and applied diagnostic IRLSSG criteria. The diagnosis of RLS was performed in $11.5 \%$ of children under 18 y.o. However, when applied to the most recent RLS criteria, only $5.9 \%$ were diagnosed as suffering from RLS. The age of onset for cases with definite RLS was 9.7 years old and probable RLS was 7.4 years. The most common complaints among children were: insomnia in $87.5 \%$; involuntary movements of the limbs in $31 \%$, chronic fatigue in $28 \%$, and inattention in $25 \%$ and sleepwalking in $9.3 \%$. A family history of RLS was present in $71 \%$ of cases and ferritin was below $50 \mathrm{ng} / \mathrm{dl}$ in $83 \%$ of cases in which it was measured ( $75 \%$ of children).

In 2007, Picchietti and colleagues ${ }^{124}$ conducted a study to assess the prevalence of RLS in children, using the criteria of IRLSSG. A prevalence of $1.9 \%$ of children between 8 and 11 years old, and $2.0 \%$ of children between 12 and 17 years old. It was also observed that children and adolescents with RLS presented insomnia in $69.4 \%, 47 \%-53 \%$ reported negative influence on mood, $46 \%-60 \%$ complained of inability to remain seated in the afternoon or evening, $29 \%-40 \%$ complained of

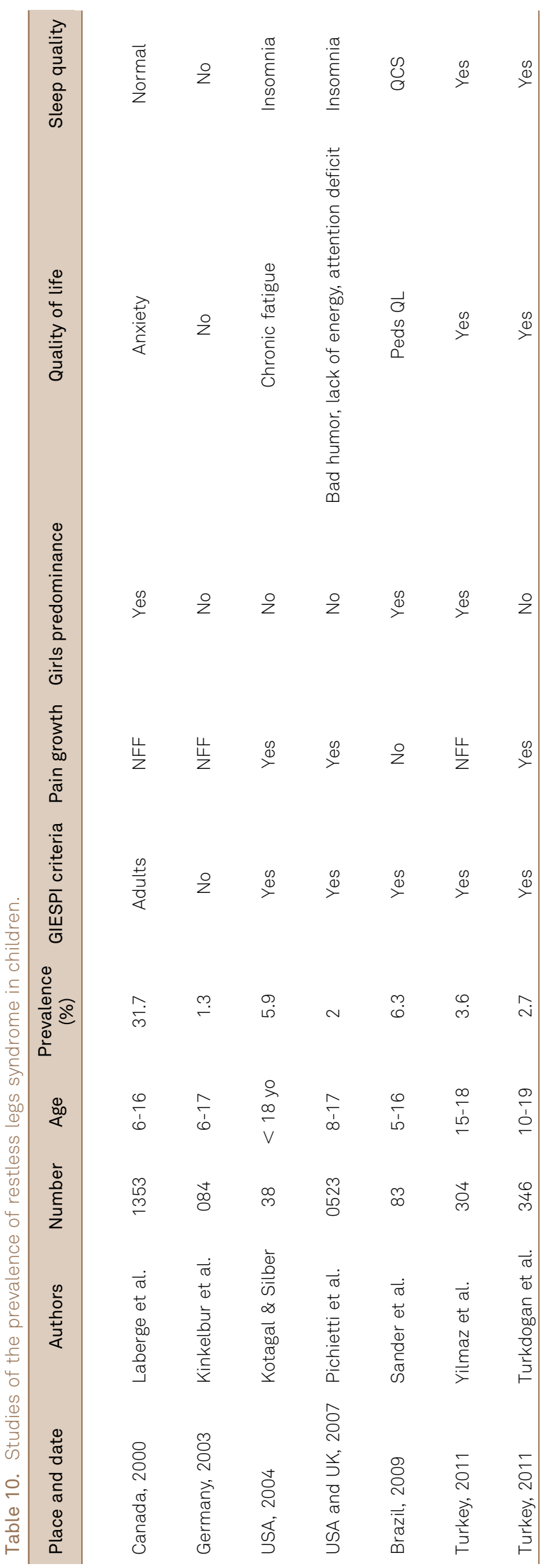


Table 11. Drugs used in Pediatric RLS.

\begin{tabular}{lccc}
\hline Drug & Dose & Level of evidence & Main indication \\
\hline Iron replacement & $50-60 \mathrm{ng}$ of iron $1-2 \times /$ day & $\mathrm{ll}$ & Primary RLS; ferritin lower than $50 \mathrm{ng} / \mathrm{dl}$ \\
Sodium valproate & $30-60 \mathrm{mg} / \mathrm{kg} / \mathrm{d}$ & $\mathrm{ll}$ & Comorbidity with epilepsy \\
Carbamazepine & $10-30 \mathrm{mg} / \mathrm{kg} / \mathrm{d}$ & $\mathrm{lb}$ & Comorbidity with epilepsy \\
Gabapentin & $100-500 \mathrm{mg}$ & $\mathrm{llb}$ & Comorbidity with epilepsy and chronic pain \\
Clonazepan & $0.01 \mathrm{mg} / \mathrm{kg}$ & $\mathrm{ll}$ & Comorbidity with epilepsy or parassomnia \\
Clonidine & $0.05-0.3 \mathrm{mg}$ & $\mathrm{ll}$ & Comorbidity with ADHD \\
Levodopa & $25 / 100 \mathrm{mg}$ & $\mathrm{ll}$ & Primary RLS with risk of augmentation \\
Pramipexole & $0.125-0.75 \mathrm{mg}$ & $\mathrm{llb}$ & Primary RLS with risk of augmentation \\
Opioids & & $\mathrm{ll}$ &
\end{tabular}

lack of energy and, among adolescents, $40 \%$ reported difficulty concentrating in school or work tasks.

In 2009, Sander et al . studied the population of school-age children in the city of the Coconut Cassia, SP, and found a prevalence of $6.3 \%$ of defined RLS ${ }^{128}$. In a epidemiological study conducted in Turkey in 2011, with children and adolescents of school age, the prevalence of defined RLS was $2.74 \%{ }^{129}$. The main epidemiological studies in children are compiled in Table 10.

\section{Treatment}

Treatment for Pediatric RLS is also divided into nonpharmacological and pharmacological. However, it is noteworthy that there are no studies with level I evidence to guide therapeutic choices of RLS in children. The non-pharmacological treatment consists in improve sleep hygiene: encourage regular physical activity and improve sleep routines in order to avoid sleep deprivation and exacerbating factors such as caffeinated substances ${ }^{130,131}$.
Pharmacological treatment is mainly based on the orally replacement of iron. Similar to the treatment in adults, dopamine agonists, anticonvulsants, benzodiazepines are referred to series of cases in the literature (level II evidence).

Oral iron is given for children and adolescents with serum ferritin less than $50 \mathrm{ng} / \mathrm{dl}$. In children above 6 years of age is recommended the use of 50-60 mg of elemental iron $1-2 x /$ day, controlling with exams every 2-3 months ${ }^{1}$. Among the anticonvulsants, there are case reports of the use of valproate, carbamazepine and gabapentin. Clonazepam is an option in cases where there are other sleep disorders (eg parasomnias) or epilepsy associated with RLS. The use of clonidine is cited in cases with comorbid RLS and ADHD. As for dopaminergic agents, studies with levodopa in children showed no safety and efficacy. There are few reports with the use of pramipexole. Regarding the opioids, which are often used in adults, they should be AVOIDED in childhood (Table 11).

\section{References}

1. Yan X, Wang WD, Walters AS, Wang Q, Liu YJ, Chu FY. Traditional Chinese medicine herbal preparations in restless legs syndrome (RLS) treatment: a review and probable first description of RLS in 1529. Sleep Med Rev. 2012;16(6):509-18. http://dx.doi.org/10.1016/j. smrv.2012.01.003

2. Sachdev P. The development of the concept of akathisia: a historical overview. Schizoph Res.1995;16(1):33-45. http://dx.doi.org/10.1016/ 0920-9964(94)00058-G

3. Willis T. The London practice of physick, or the whole practical part of physick contained in the works of Dr. Willis. London: Thomas Basset and William Crooke; 1685.

4. Teive HA, Munhoz RP, Barbosa ER. Professor Karl-Axel Ekbom and restless legs syndrome. Parkinsonism Related Disord. 2009;15(4):254-7. http://dx.doi.org/10.1016/j.parkreldis.2008.07.011

5. Nordlander NB. Therapy in restless legs. Acta Med Scand. 1953;145(6):453-57. http://dx.doi.org/10.1111/j.0954-6820.1953.tb07042.x

6. Coccagna G, Vetrugno R, Lombardi C, Provini F. Restless legs syndrome: an historical note. Sleep Med. 2004;5(3):279-83. http:// dx.doi.org/10.1016/j.sleep.2004.01.002

7. Akpinar S. Treatment of restless legs syndrome with levodopa plus benserazide. Arch Neurol. 1982;39(11):739. http://dx.doi.org/10.1001/ archneur.1982.00510230065027

8. Eckeli AL, Gitaí LL, Dach F, Ceretta H, Sander HH, Passos AD et al. Prevalence of restless legs syndrome in the rural town of Cassia dos
Coqueiros in Brazil. Sleep Med. 2011;12(8):762-7. http://dx.doi.org/ 10.1016/j.sleep.2011.01.018

9. Hening W, Walters AS, Allen RP, Montplaisir J, Myers A, FeriniStrambi L. Impact, diagnosis and treatment of restless legs syndrome (RLS) in a primary care population: the REST (RLS epidemiology, symptoms, and treatment) primary care study. Sleep Med. 2004;5(3):237-46. http://dx.doi.org/10.1016/j.sleep.2004.03. 006

10. Allen RP, Picchietti D, Hening WA, Trenkwalder C, Walters AS, Montplaisi $J$ et al. Restless legs syndrome: diagnostic criteria, special considerations, and epidemiology. A report from the restless legs syndrome diagnosis and epidemiology workshop at the National Institutes of Health. Sleep Med. 2003;4(2):101-19. http://dx.doi.org/ 10.1016/\$1389-9457(03)00010-8

11. International Restless Legs Syndrome Study Group. Revised diagnostic criteria. 2011 [cited 2013 May]. Available from: http://irlssg. org/diagnostic-criteria/

12. American Academy of Sleep Medicine. The international classification of sleep disorders : diagnostic and coding manual. 2nd ed. Westchester: American Academy of Sleep Medicine; 2005.

13. Benes H, Walters AS, Allen RP, Hening WA, Kohnen R. Definition of restless legs syndrome, how to diagnose it, and how to differentiate it from RLS mimics. Mov Disord. 2007;22(Suppl 18):S401-8. http://dx. doi.org/10.1002/mds. 21604 
14. Karroum EG, Golmard JL, Leu-Semenescu S, Arnulf I. Sensations in restless legs syndrome. Sleep Med. 2012;13(4):402-8. http://dx.doi. org/10.1016/j.sleep.2011.01.021

15. Kerr S, McKinon W, Bentley A. Descriptors of restless legs syndrome sensations. Sleep Med. 2012;13(4):409-13. http://dx.doi.org/10.1016/ j.sleep.2011.11.020

16. Stiasny-Kolster K, Kohnen R, Möller JC, Trenkwalder C, Oertel WH. Validation of the "L-DOPA test" for diagnosis of restless legs syndrome. Mov Disord. 2006;21(9):1333-9. http://dx.doi.org/ $10.1002 /$ mds. 20969

17. Allen RP, Walters AS, Montplaisir J, et al. Restless legs syndrome prevalence and impact: REST general population study. Arch Intern Med. 2005;165(11):1286-92. http://dx.doi.org/10.1001/archinte.165.11.1286

18. Cho YW, Shin WC, Yun CH, Hong SB, Kim JH, Allen RP et al. Epidemiology of restless legs syndrome in Korean adults. Sleep. 2008;31(2):219-23.

19. Phillips B, Hening W, Britz P, Mannino D. Prevalence and correlates of restless legs syndrome: results from the 2005 National Sleep Foundation Poll. Chest. 2006;129(1):76-80. http://dx.doi.org/ 10.1378/chest.129.1.76

20. Vogl FD, Pichler I, Adel S, Pinggera GK, Bracco S, De Grandi A et al. Restless legs syndrome: epidemiological and clinicogenetic study in a South Tyrolean population isolate. Mov Disord. 2006;21(8):1189-95. http://dx.doi.org/10.1002/mds.20922

21. Pantaleo NP, Hening WA, Allen RP, Earley CJ. Pregnancy accounts for most of the gender difference in prevalence of familial RLS. Sleep Med. 2010;11(3):310-3. http://dx.doi.org/10.1016/j.sleep.2009.04. 005

22. Tasdemir M, Erdoğan H, Börü UT, Dilaver E, Kumas A. Epidemiology of restless legs syndrome in Turkish adults on the western Black Sea coast of Turkey: A door-to-door study in a rural area. Sleep Med. 2010;11(1):82-6. http://dx.doi.org/10.1016/j.sleep.2008.10.008

23. Li Y, Wang W, Winkelman JW, Malhotra A, Ma J, Gao X. Prospective study of restless legs syndrome and mortality among men. Neurology. 2013;81(1):52-9. http://dx.doi.org/10.1212/WNL.0b013e318297eee0

24. Allen RP, Earley CJ. Restless legs syndrome: a review of clinical and pathophysiologic features. J Clin Neurophysiol. 2001;18(2):128-47. http://dx.doi.org/10.1097/00004691-200103000-00004

25. Garcia-Borreguero D, Stillman P, Benes H, Buschmann H, Chaudhuri KR, Gonzalez Rodríguez VM et al. Algorithms for the diagnosis and treatment of restless legs syndrome in primary care. BMC Neurol. 2011;11(1):28. http://dx.doi.org/10.1186/1471-2377-11-28

26. LaBan MM, Viola SL, Femminineo AF, Taylor RS. Restless legs syndrome associated with diminished cardiopulmonary compliance and lumbar spinal stenosis-a motor concomitant of "Vesper's curse". Arch Phys Med Rehabil. 1990;71(6):384-8.

27. Rodrigues RN, Rodrigues AA, Corso JT, Peixoto TF. Restless legs syndrome associated with cardiac failure and aggravated after valvular replacement: Vesper's curse? Arq Neuropsiquiatr. 2008;66(3A):539-41. http://dx.doi.org/10.1590/S0004-282X2008000400019

28. Rajaram SS, Walters AS, England SJ, Mehta D, Nizam F. Some children with growing pains may actually have restless legs syndrome. Sleep. 2004;27(4):767-73.

29. Hoque R, Chesson JR AL. Pharmacologically induced/exacerbated restless legs syndrome, periodic limb movements of sleep, and REM behavior disorder/REM sleep without atonia: literature review, qualitative scoring, and comparative analysis. J Clin Sleep Med. 2010;6(1):79-83.

30. O’Keeffe ST, Gavin K, Lavan JN. Iron status and restless legs syndrome in the elderly. Age Ageing. 1994;23(3):200-3. http://dx.doi.org/ 10.1093/ageing/23.3.200

31. Sun ER, Chen CA, Ho G, Earley CJ, Allen RP. Iron and the restless legs syndrome. Sleep. 1998;21(4):371-7.
32. Montplaisir J, Boucher S, Poirier G, Lavigne G, Lapierre O, Lespérance P. Clinical, polysomnographic, and genetic characteristics of restless legs syndrome: a study of 133 patients diagnosed with new standard criteria. Mov Disord. 1997;12(1):61-5. http://dx.doi.org/10.1002/mds. 870120111

33. Grupo Brasileiro de Estudos. Síndrome de Pernas Inquietas. [Restless legs syndrome: diagnosis and treatment. Opinion of Brazilian experts]. Arq Neuropsiq. 2007;65(3A):721-7. Portuguese. http://dx.doi.org/10.1590/S0004-282X2007000400035

34. Morgenthaler T, Alessi C, Friedman L, Owens J, Kapur V, Boehlecke B et al. Practice parameters for the use of actigraphy in the assessment of sleep and sleep disorders: an update for 2007. Sleep. 2007;30(4):519-29.

35. Montplaisir J, Boucher S, Nicolas A, Lesperance P, Gosselin A, Rompré $P$ et al. Immobilization tests and periodic leg movements in sleep for the diagnosis of restless leg syndrome. Mov Disord. 1998;13(2):324-9. http://dx.doi.org/10.1002/mds.870130220

36. Portaluppi F, Cortelli P, Buonaura GC, Smolensky MH, Fabbian F. Do restless legs syndrome (RLS) and periodic limb movements of sleep (PLMS) play a role in nocturnal hypertension and increased cardiovascular risk of renally impaired patients? Chronobiol Int. 2009;26(6):1206-21. http://dx.doi.org/10.3109/07420520903245276

37. Walters AS, Rye DB. Review of the relationship of restless legs syndrome and periodic limb movements in sleep to hypertension, heart disease, and stroke. Sleep. 2009;32(5):589-97.

38. Giannaki CD, Zigoulis P, Karatzaferi C, et al. Periodic limb movements in sleep contribute to further cardiac structure abnormalities in hemodialysis patients with restless legs syndrome. J Clin Sleep Med. 2013;9(2):147-53.

39. Lindner A, Fornadi K, Lazar AS, Czira ME, Dunai A, Zoller R et al. Periodic limb movements in sleep are associated with stroke and cardiovascular risk factors in patients with renal failure. J Sleep Res. 2012;21(3):297-307. http://dx.doi.org/10.1111/j.1365-2869.2011.00956.x

40. Ulfberg J, Nyström B, Carter N, Edling C. Prevalence of restless legs syndrome among men aged 18 to 64 years: an association with somatic disease and neuropsychiatric symptoms. Mov Disord. 2001;16(6):1159-63. http://dx.doi.org/10.1002/mds.1209

41. Ohayon MM, Roth T. Prevalence of restless legs syndrome and periodic limb movement disorder in the general population. J Psychosom Res. 2002;53(1):547-54. http://dx.doi.org/10.1016/ S0022-3999(02)00443-9

42. Winkelman JW, Finn L, Young T. Prevalence and correlates of restless legs syndrome symptoms in the Wisconsin Sleep Cohort. Sleep Med. 2006;7(7):545-52. http://dx.doi.org/10.1016/j.sleep.2006.01.004

43. Winkelman JW, Shahar E, Sharief I, Gottlieb DJ. Association of restless legs syndrome and cardiovascular disease in the Sleep Heart Health Study. Neurology. 2008;70(1):35-42. http://dx.doi.org/ 10.1212/01.wnl.0000287072.93277.c9

44. Batool-Anwar S, Malhotra A, Forman J, Winkelman J, Li Y, Gao X. Restless legs syndrome and hypertension in middle-aged women. Hypertension. 2011;58(5):791-6. http://dx.doi.org/10.1161/ HYPERTENSIONAHA.111.174037

45. Winter AC, Schürks M, Glynn RJ, et al. Vascular risk factors, cardiovascular disease, and restless legs syndrome in women. Am J Med. 2013;126(3):220-7.e2. http://dx.doi.org/10.1016/j.amjmed. 2012.06.040

46. Li Y, Walters AS, Chiuve SE, Rimm EB, Winkelman JW, Gao X. Prospective study of restless legs syndrome and coronary heart disease among women. Circulation. 2012;126(14):1689-94. http://dx. doi.org/10.1161/CIRCULATIONAHA.112.112698

47. Winter AC, Schürks M, Glynn RJ, et al. Restless legs syndrome and risk of incident cardiovascular disease in women and men: prospective cohort study. BMJ open 2012;2(2):e000866. http://dx. doi.org/10.1136/bmjopen-2012-000866 
48. Mallon L, Broman JE, Hetta J. Restless legs symptoms with sleepiness in relation to mortality: 20-year follow-up study of a middle-aged Swedish population. Psychiatry Clin Neurosci. 2008;62:457-63. http://dx.doi.org/10.1111/j.1440-1819.2008.01831.x

49. Szentkirályi A, Winter AC, Schürks M, Völzke H, Hoffmann W, Buring $\mathrm{JE}$ et al. Restless legs syndrome and all-cause mortality in four prospective cohort studies. BMJ Open 2012;2(6): e001652. http://dx. doi.org/10.1136/bmjopen-2012-001652

50. Winter AC, Berger K, Glynn RJ, et al. Vascular risk factors, cardiovascular disease, and restless legs syndrome in men. Am J Med. 2013;126(3):228-35e2. http://dx.doi.org/10.1016/j.amjmed.2012.06.039

51. Aurora RN, Kristo DA, Bista SR, Rowley JA, Zak RS, Casey KR et al. The treatment of restless legs syndrome and periodic limb movement disorder in adults-an update for 2012: practice parameters with an evidence-based systematic review and meta-analyses: an American Academy of Sleep Medicine Clinical Practice Guideline. Sleep. 2012;35(8):1039-62. http://dx.doi.org/10.5665/sleep.1988

52. Scholz H, Trenkwalder C, Kohnen R, Kriston L, Riemann D, Hornyak M. Levodopa for the treatment of restless legs syndrome. Cochrane Database of Systematic Rev. 2013(4). http://dx.doi.org/10.1002/ 14651858.CD005504.pub2

53. Montplaisir J, Fantini ML, Desautels A, Michaud M, Petit D, Filipini D. Long-term treatment with pramipexole in restless legs syndrome. Eur J Neurol. 2006;13(12):1306-11. http://dx.doi.org/10.1111/j.14681331.2006.01459.x

54. Inoue Y, Kuroda K, Hirata K, Uchimura N, Kagimura T, Shimizu T. Long-term open-label study of pramipexole in patients with primary restless legs syndrome. J Neurol Sci. 2010;294(1-2):62-6. http://dx. doi.org/10.1016/j.jns.2010.04.003

55. Partinen M, Hirvonen K, Jama L, Alakuijala A, Hublin C, Tamminen I et al. Open-label study of the long-term efficacy and safety of pramipexole in patients with Restless Legs Syndrome (extension of the PRELUDE study). Sleep Med. 2008;9(5):537-41. http://dx.doi.org/ 10.1016/j.sleep.2007.12.004

56. Evidente VG. Piribedil for restless legs syndrome: a pilot study. Mov Disord. 2001;16(3):579-81. http://dx.doi.org/10.1002/mds.1104

57. Garcia-Borreguero D, Ferini-Strambi L, Kohnen R, O'Keeffe S, Trenkwalder C, Högl B et al. European guidelines on management of restless legs syndrome: report of a joint task force by the European Federation of Neurological Societies, the European Neurological Society and the European Sleep Research Society. Eur J Neurol. 2012;19(11):1385-96. http://dx.doi.org/10.1111/j.14681331.2012.03853.x

58. Cornelius JR, Tippmann-Peikert M, Slocumb NL, Frerichs CF, Silber $\mathrm{MH}$. Impulse control disorders with the use of dopaminergic agents in restless legs syndrome: a case-control study. Sleep. 2010;33(1):81-7.

59. Ondo WG, Lai D. Predictors of impulsivity and reward seeking behavior with dopamine agonists. Parkinsonism Relat Disord. 2008;14(1):28-32. http://dx.doi.org/10.1016/j.parkreldis.2007.05.006

60. Driver-Dunckley ED, Noble BN, Hentz JG, Evidente VG, Caviness JN, Parish $J$ et al. Gambling and increased sexual desire with dopaminergic medications in restless legs syndrome. Clin Neuropharmacol. 2007;30(5):249-55. http://dx.doi.org/10.1097/wnf.0b013e31804c780e

61. O'Sullivan SS, Evans AH, Lees AJ. Dopamine dysregulation syndrome: an overview of its epidemiology, mechanisms and management. CNS Drugs. 2009;23(2):157-70. http://dx.doi.org/10.2165/00023210-200923020-00005

62. Trenkwalder C, Hundemer HP, Lledo A, Swieca J, Poo O, Wetter TC et al. Efficacy of pergolide in treatment of restless legs syndrome: the PEARLS Study. Neurology. 2004;62(8):1391-7. http://dx.doi.org/ 10.1212/01.WNL.0000124465.20878.84

63. Zanettini R, Antonini A, Gatto G, Gentile R, Tesei S, Pezzoli G. Valvular heart disease and the use of dopamine agonists for Parkinson's disease. N Engl J Med. 2007;356(1):39-46. http://dx.doi.org/10.1056/ NEJMoa054830
64. Elenkova A, Shabani R, Kalinov K, Zacharieva S. Increased prevalence of subclinical cardiac valve fibrosis in patients with prolactinomas on long-term bromocriptine and cabergoline treatment. Eur J Endocrinol. 2012;167(1):17-25. http://dx.doi.org/10.1530/EJE-12-0121

65. Benes $H$. Transdermal lisuride: short-term efficacy and tolerability study in patients with severe restless legs syndrome. Sleep Med. 2006;7(1):31-5. http://dx.doi.org/10.1016/j.sleep.2005.05.007

66. Hofmann C, Penner U, Dorow R, Pertz HH, Jähnichen S, Horowski R et al. Lisuride, a dopamine receptor agonist with 5-HT2B receptor antagonist properties: absence of cardiac valvulopathy adverse drug reaction reports supports the concept of a crucial role for 5-HT2B receptor agonism in cardiac valvular fibrosis. Clin Neuropharmacol. 2006;29(2):80-6. http://dx.doi.org/10.1097/00002826-200603000-00005

67. Hornyak M, Trenkwalder C, Kohnen R, Scholz H. Efficacy and safety of dopamine agonists in restless legs syndrome. Sleep Med. 2012;13(3):228-36. http://dx.doi.org/10.1016/j.sleep.2011.09.013

68. Garcia-Borreguero D, Larrosa O, Llave Y, Verger K, Masramon X, Hernandez G. Treatment of restless legs syndrome with gabapentin: a double-blind, cross-over study. Neurology. 2002;59(10):1573-9. http://dx.doi.org/10.1212/WNL.59.10.1573

69. Happe S, Sauter C, Klösch G, Saletu B, Zeitlhofer J. Gabapentin versus ropinirole in the treatment of idiopathic restless legs syndrome. Neuropsychobiology. 2003;48(2):82-6. http://dx.doi.org/ $10.1159 / 000072882$

70. Thorp ML, Morris CD, Bagby SP. A crossover study of gabapentin in treatment of restless legs syndrome among hemodialysis patients. Am J Kidney Dis. 2001;38(1):104-8. http://dx.doi.org/10.1053/ ajkd.2001.25202

71. Micozkadioglu H, Ozdemir FN, Kut A, Sezer S, Saatci U, Haberal M. Gabapentin versus levodopa for the treatment of Restless Legs Syndrome in hemodialysis patients: an open-label study. Ren Fail. 2004;26(4):393-7. http://dx.doi.org/10.1081/JDI-120039823

72. Allen R, Chen C, Soaita A, Wohlberg C, Knapp L, Peterson BT et al. A randomized, double-blind, 6-week, dose-ranging study of pregabalin in patients with restless legs syndrome. Sleep Med. 2010;11(6):512-9.

73. Garcia-Borreguero D, Larrosa O, Williams AM, Albares J, Pascual M, Palacios JC et al. Treatment of restless legs syndrome with pregabalin: a double-blind, placebo-controlled study. Neurology. 2010;74(23):1897-904. http://dx.doi.org/10.1212/WNL.0b013e3181e1ce73

74. Sommer M, Bachmann CG, Liebetanz KM, Schindehütte J, Tings T, Paulus W. Pregabalin in restless legs syndrome with and without neuropathic pain. Acta Neurol Scand. 2007;115(5):347-50. http://dx. doi.org/10.1111/j.1600-0404.2007.00796.x

75. Walters AS, Wagner ML, Hening WA, Grasing K, Mills R, Chokroverty S et al. Successful treatment of the idiopathic restless legs syndrome in a randomized double-blind trial of oxycodone versus placebo. Sleep. 1993;16(4):327-32.

76. Kaplan PW, Allen RP, Buchholz DW, Walters JK. A double-blind, placebo-controlled study of the treatment of periodic limb movements in sleep using carbidopa/levodopa and propoxyphene. Sleep. 1993;16(8):717-23.

77. Lauerma H, Markkula J. Treatment of restless legs syndrome with tramadol: an open study. J Clin Psychiatry. 1999;60(4):241-4. http:// dx.doi.org/10.4088/JCP.v60n0407

78. Walters AS, Winkelmann J, Trenkwalder C, Fry JM, Kataria V, Wagner $M$ et al. Long-term follow-up on restless legs syndrome patients treated with opioids. Mov Disord. 2001;16(6):1105-9. http://dx.doi. org/10.1002/mds.1214

79. Ondo WG. Methadone for refractory restless legs syndrome. Mov Disord. 2005;20(3):345-8. http://dx.doi.org/10.1002/mds.20359

80. Silver N, allen RP, Senerth J, Earley CJ et al. A 10-year, longitudinal assessment of dopamine agonists and methadone in the treatment of restless legs syndrome. Sleep Med. 2011;12(5):440-4. http://dx. doi.org/10.1016/j.sleep.2010.11.002 
81. Hening WA. Current guidelines and standards of practice for restless legs syndrome. Amer J Med. 2007;120(1 suppl 1):S22-7. http://dx.doi. org/10.1016/j.amjmed.2006.11.004

82. Vetrugno R, La Morgia C, D’Angelo R, Loi D, Provini F, Plazzi G et al. Augmentation of restless legs syndrome with long-term tramadol treatment. Mov Disord. 2007;22(3):424-7. http://dx.doi.org/10.1002/ mds. 21342

83. Trotti LM, Bhadriraju S, Becker LA. Iron for Restless Legs Syndrome. Cochrane Database Syst Rev. 2013;3: CD007834. http://dx.doi.org/ 10.1002/14651858.CD007834.pub5

84. Allen RP, Butcher A, Du W. Double-blind, placebo-controlles muti-center avaluation of restlelss legs syndrome (RLS) treatment with a 1,000 mg of IV iron (ferric carboxymaltose - FCM). Sleep. 2009;32:A294-5. Documento não encontrado; solicitor aos autores que confirmem os dados.

85. Davis BJ, Rajput A, Aul EA, Eichhorn GR. A randomized, double-blind, placebo-controlled trial of iron in restless legs syndrome. Eur Neurol. 2000;43(2):70-5. http://dx.doi.org/10.1159/000008138

86. Earley CJ, Horská A, Mohamed MA, Barker PB, Beard Jl, Allen RP. A randomized, double-blind, placebo-controlled trial of intravenous iron sucrose in restless legs syndrome. Sleep Med. 2009;10(2):206-11.

87. Grote L, Leissner L, Hedner J, Ulfberg J. A randomized, double-blind, placebo controlled multi-center study of intravenous iron sucrose and placebo in the treatment of restless legs syndrome. Mov Disord. 2009;24(10):1445-52. http://dx.doi.org/10.1002/mds.22562

88. Sloand JA, Shelly MA, Feigin A, Bernstein P, Monk RD. A double-blind, placebo-controlled trial of intravenous iron dextran therapy in patients with ESRD and restless legs syndrome. Am J Kidney Dis. 2004;43(4):663-70. http://dx.doi.org/10.1053/j.ajkd.2003.11.021

89. Wang J, O’Reilly B, Venkataraman R, Mysliwiec V, Mysliwiec A. Efficacy of oral iron in patients with restless legs syndrome and a low-normal ferritin: a randomized, double-blind, placebo-controlled study. Sleep Med. 2009;10(9):973-5. http://dx.doi.org/10.1016/j. sleep.2008.11.003

90. Telstad W, Sørensen O, Larsen S, Lillevold PE, Stensrud P, NybergHansen R. Treatment of the restless legs syndrome with carbamazepine: a double blind study. Br Med J (Clin Res Ed). 1984;288(6415):444-6. http://dx.doi.org/10.1136/bmj.288.6415.444

91. Lundvall O, Abom PE, Holm R. Carbamazepine in restless legs. A controlled pilot study. Eur J Clin Pharmacol. 1983;25(3):323-4. http://dx.doi.org/10.1007/BF01037942

92. Eisensehr I, Ehrenberg BL, Rogge Solti S, S Noachtar Treatment of idiopathic restless legs syndrome (RLS) with slow-release valproic acid compared with slow -release levodopa/benserazid. J Neurol. 2004;251(5):579-83. http://dx.doi.org/10.1007/s00415-004-0367-6

93. Boghen D, Lamothe L, Elie R, Godbout R, Montplaisir J. The treatment of the restless legs syndrome with clonazepam: a prospective controlled study. Can J Neurol Sci. 1986;13(3):245-7.

94. Montagna P, Sassoli de Bianchi L, Zucconi M, Cirignotta F, Lugaresi E. Clonazepam and vibration in restless legs syndrome. Acta Neurol Scand. 1984;69(6):428-30. http://dx.doi.org/10.1111/j.1600-0404. 1984.tb07826.x

95. Saletu M, Anderer P, Saletu-Zyhlarz G, Prause W, Semler B, Zoghlami $A$, et al. Restless legs syndrome (RLS) and periodic limb movement disorder (PLMD): acute placebo-controlled sleep laboratory studies with clonazepam. Eur Neuropsychopharmacol. 2001;11(2):153-61. http://dx.doi.org/10.1016/S0924-977X(01)00080-3

96. Wagner ML, Walters AS, Coleman RG, Hening WA, Grasing K, Chokroverty S. Randomized, double-blind, placebo-controlled study of clonidine in restless legs syndrome. Sleep. 1996;19(1):52-8 .

97. Cuellar NG, Ratcliffe SJ. Does valerian improve sleepiness and symptom severity in people with restless legs syndrome? Altern Ther Health Med. 2009;15(2):22-8.
98. Bayard M, Bailey B, Acharya D, Ambreen F, Duggal S, Kaur T et al. Bupropion and restless legs syndrome: a randomized controlled trial. J Am Board Fam Med. 2011;24(4):422-8. http://dx.doi.org/10.3122/ jabfm.2011.04.100173

99. Nahab FB, Peckham EL, Hallett M. Double-blind, placebo-controlled, pilot trial of botulinum toxin A in restless legs syndrome. Neurology. 2008;71(12):950-1. http://dx.doi.org/10.1212/01.wnl.0000325994. 93782.a1

100. Agarwal P, Sia C, Vaish N, Roy-Faderman I. Pilot trial of onabotulinumtoxina (Botox) in moderate to severe restless legs syndrome. Int J Neurosci. 2011;121(11):622-5. http://dx.doi.org/10.3109/ 00207454.2011 .602774

101. Aukerman MM, Aukerman D, Bayard M, Tudiver F, Thorp L, Bailey B. Exercise and restless legs syndrome: a randomized controlled trial. $J$ Am Board Fam Med. 2006;19(5):487-93. http://dx.doi.org/10.3122/ jabfm.19.5.487

102. Lettieri CJ, Eliasson AH. Pneumatic compression devices are an effective therapy for restless legs syndrome: a prospective, randomized, double-blinded, sham-controlled trial. Chest. 2009;135 (1):74-80. http://dx.doi.org/10.1378/chest.08-1665

103. Mitchell UH, Myrer JW, Johnson AW, Hilton SC. Restless legs syndrome and near-infrared light: An alternative treatment option. Physiother Theory Pract. 2011;27(5):345-51. http://dx.doi.org/ 10.3109/09593985.2010.511440

104. Cui Y, Wang Y, Liu Z. Acupuncture for restless legs syndrome. Cochrane Database Syst Rev. 2008(4):CD006457. http://dx.doi.org/ 10.1002/14651858.CD006457.pub2

105. Rajaram SS, Rudzinskiy P, Walters AS. Enhanced external counter pulsation (EECP) for restless legs syndrome (RLS): preliminary negative results in a parallel double-blind study. Sleep Med. 2006;7(4):390-1. http://dx.doi.org/10.1016/j.sleep.2006.03.008

106. Garcia-Borreguero D, Williams AM. Dopaminergic augmentation of restless legs syndrome: the scope of the problem. Sleep Med. 2011;12(5):425-6. http://dx.doi.org/10.1016/j.sleep.2011.03.004

107. García-Borreguero D, Williams AM. Dopaminergic augmentation of restless legs syndrome. Sleep Med Rev. 2010;14(5):339-46. http://dx. doi.org/10.1016/j.smrv.2009.11.006

108. Allen RP, Ondo WG, Ball E, Calloway MO, Manjunath R, Higbie RL et al. Restless legs syndrome (RLS) augmentation associated with dopamine agonist and levodopa usage in community sample Sleep Med. 2011;12(5):431-9. http://dx.doi.org/10.1016/j.sleep.2011.03.003

109. Garcla-Borreguero D, Allen RP, Kohnen R, Högl B Trenkwalder C, Oertel $\mathrm{W}$ et al. Diagnostic standards for dopaminergic augmentation of restless legs syndrome: report from the World Association of Sleep Medicine-International Restless Legs Syndrome Study Group consensus on conference at the Max Planck Institute. Sleep Med. 2007;8 (5):520-30. http://dx.doi.org/10.1016/j.sleep.2007.03.022

110. Beneš H, García-Borreguero D, Ferini-Strambi L, Schollmayer E, Fichtner A, Kohnen R. Augmentation in the treatment of restless legs syndrome with rotigotine transdermal Sleep Med. 2012;13:589-97. http://dx.doi.org/10.1016/j.sleep.2011.09.016

111. Sivam S, Yee BJ. Role of gabapentin enacarbil XR in restless legs syndrome. Ther Clin Risk Manag. 2012;8:201-8. http://dx.doi.org/ 10.2147/TCRM.S24436

112. Ekbom, KA. Restless legs: a clinical study of a hitherto overlooked disease in the legs characterized by peculiar paresthesia ("Anxietas Tibiarum"), pain and weakness and occuring in two main forms, asthenia crurum paraesthesica and asthenia crurum dolorosa. A Short Review of Paresthesia in General. Acta Med Scand. 1945;Suppl. 158:1-123.

113. Walters AS, Picchietti DL, Ehrenberg BL, Wagner ML. Restless legs syndrome in childhood and adolescence. Pediatr Neurol. 1994;11(3):241-5. http://dx.doi.org/10.1016/0887-8994(94)90110-4 
114. Picchetti DL, Bruni O, Weerd A, Durmer JS, Kotagal S, Owens JA et al. Pediatric restless legs syndrome diagnostic criteria: an update by the International Restless Legs Syndrome Study Group. Sleep Med. 2013;14(12):1253-9. http://dx.doi.org/10.1016/j.sleep.2013.08.778

115. Simakajornboon N, Kheirandish-Gozal L, Gozal D. Diagnosis and management of restless legs syndrome in children. Sleep Med Rev. 2009;13(2):149-56. http://dx.doi.org/10.1016/j.smrv.2008.12

116. Peterson. Growing pains. Pediatr Clin North Am. 1986;33(6):1365-72.

117. Walters AS. Is there a subpopulation of children with growing pains who really have Restless Legs Syndrome: a review of the literature. Sleep Med. 2002;3(2):93-8. http://dx.doi.org/10.1016/S1389-9457(01)00164-2

118. Cortese S, Konofal E, Lecendreux M, Arnulf I, Mouren MC, Darra F et al. Restless legs syndrome and attention-deficit/hyperactivity disorder: a review of the literature. Sleep. 2005;28(8):1007-13.

119. Picchietti MA, Picchietti DL. Restless legs syndrome and periodic limb movement disorder in children and adolescents. Semin Pediatr Neurol. 2008;15(2):91-9. http://dx.doi.org/10.1016/j.spen.2008.03.005

120. Walters AS, Mandelbaum DE, Lewin DS, Kugler S, England SJ, Miller M. Dopaminergic therapy in children with restless legs periodic limb movements in sleep and ADHD. Pediatr Neurol. 2000;22(3):182-6. http://dx.doi.org/10.1016/S0887-8994(99)00152-6

121. Schormair B, Kemlink D, Roeske D, Eckstein G, Xiong L, Lichtner P et al. PTPRD (protein tyrosine phosphatase receptor type delta) is associated with restless legs syndrome. Nat Genet. 2008;40(8):946-8. http://dx.doi.org/10.1038/ng.190

122. Pullen SJ, Wall CA, Angstman ER, Munitz GE, Kotagal S. Psychiatric comorbidity in children and adolescents with restless legs syndrome: a retrospective study. J Clin Sleep Med. 2011;7(6):587-96. http://dx.doi.org/10.5664/jcsm.1456
123. Walters AS, Hickey K, Maltzman J, Verrico T, Joseph D, Hening W et al. A questionnaire study of 138 patients with restless legs syndrome: the "Night-Walkers" survey. Neurology. 1996;46(1):92-5. http://dx.doi.org/10.1212/WNL.46.1.92

124. Picchietti D, Allen RP, Walters AS, Davidson JE, Myers A, FeriniStrambi L. Restless legs syndrome: prevalence and impact in children and adolescents-the Peds REST study. Pediatrics. 2007;120(2):253-66. http://dx.doi.org/10.1542/peds.2006-2767

125. Laberge L, Tremblay RE, Vitaro F, Montplaisir J. Development of parasomnias from chidhood to early adolescence. Pediatrics. 2000;106:67-74.

126. Kinkelbur J, Hellwig, J, Hellwig, M. Frequency of RLS symptoms in childhood. Somnologie. 2003;7(Suppl 1):34

127. Kotagal S, Silber $\mathrm{MH}$. Childhood-onset restless legs syndrome. Ann Neurol. 2004;56(6):803-7. http://dx.doi.org/10.1002/ana.20292

128. Sander HH. Síndrome das pernas inquietas em crianças: prevalência, características, impacto no sono e na qualidade de vida no município de Cássia dos Coqueiros, São Paulo, Brasil [tese de doutorado]. Ribeirão Preto: Faculdade de Medicina de Ribeirão Preto da Universidade de São Paulo; 2009.

129. Turkdogan D, Bekiroglu N, Zaimoglu S. A prevalence study of restless legs syndrome in Turkish children and adolescents. Sleep Med. 2011;12(4):315-21. http://dx.doi.org/10.1016/j.sleep.2010.08.013

130. Ylmaz K, Kilincaslan A, Aydin N, Kor D. Prevalence and correlates of restless legs syndrome in adolescents. Dev Med Child Neurol. 2010. http://dx.doi.org/10.1111/j.1469-8749.2010.03796.x

131. Frenette, E. Restless legs syndrome in children: a review and update on pharmacological options. Curr Pharm Des. 2011;17(15):1436-42. 17(15):1436-1442. http://dx.doi.org/10.2174/138161211796197142 